\title{
7. FISSION-TRACK ANALYSIS OF DETRITAL APATITES FROM SITES 7I7 AND 718, LEG 116, CENTRAL INDIAN OCEAN1
}

\author{
Jeff D. Corrigan ${ }^{2}$ and Kevin D. Crowley ${ }^{3}$
}

\begin{abstract}
This paper presents fission-track ages and confined track-length measurements from detrital apatites recovered from Ocean Drilling Program Leg 116 Site 717 and 718 cores. We interpret these data in terms of the post-depositional thermal history at these two sites and the thermotectonic history of apatite source areas. Composite apatite samples were derived by combining fine-grained sand samples from Sites 717 and 718 cores over $70-$ to $120-\mathrm{m}$ intervals over the total depth penetrated at Sites 717 (T.D. $=820 \mathrm{mbsf}$ ) and 718 (T.D. $=960 \mathrm{mbsf}$ ). Thirty apatite grains per composite sample from ten samples (at least every other sampled interval) were dated and track-length measurements (20-50 per sample) were obtained for all samples.

Mean track lengths from Site 717 samples are statistically identical, ranging from $14.4 \pm 0.4$ to $14.8 \pm 0.3 \mu \mathrm{m}$ (all errors are the $95 \%$ confidence interval), and mean fission-track ages increase monotonically downhole from $4.8 \pm$ 1.1 to $14.3 \pm 2.3 \mathrm{Ma}$. For Site 718 , located approximately $7 \mathrm{~km}$ to the south of Site 717 on an adjacent fault block, mean track lengths to 560 mbsf are equivalent to those measured from Site 717 samples. A decrease in mean track length $(14.6 \pm 0.3$ to $13.2 \pm 0.4 \mu \mathrm{m})$ and a corresponding decrease in mean fission-track age $(21.1 \pm 2.9$ to $15.8 \pm$ $2.4 \mathrm{Ma}$ ) with depth for samples between 560 and $960 \mathrm{mbsf}$ from Site 718 indicates that post-depositional downhole shortening of fission tracks at elevated temperatures has taken place.

Track-length shortening, based on mean track lengths relative to an unannealed mean track length of $16.3 \mu \mathrm{m}$, is approximately $10 \%$ for all Site 717 samples and for samples from the upper $560 \mathrm{~m}$ of Site 718 . The total amount of shortening of the lowermost sample from Site 718 is approximately $20 \%$. Based on extrapolation of published laboratory annealing experiments, maximum isothermal time-temperature condition extremes that could produce this degree of annealing at the base of Site 718 are estimated to range from $50^{\circ} \mathrm{C}$ for a duration of $17 \mathrm{~m} . \mathrm{y}$. (since deposition) to $55^{\circ} \mathrm{C}$ for a duration of $7.5 \mathrm{~m} . \mathrm{y}$. (since the onset of deformation). These estimates argue against regional thermal conduction as the only mechanism for post-depositional heating and support seafloor heat flow and shipboard geochemical evidence for local convective heat transfer in the vicinity of Site 718 .

In terms of source-area implications, dated samples have mean apatite fission-track ages that are only 0 to 10 m.y. older than depositional ages. These young ages imply rapid transport of sediment to the distal Bengal Fan and source areas characterized by high denundation rates $(\leq 300 \mathrm{~m} / \mathrm{m} . \mathrm{y}$.). These rates suggest that source areas similar to parts of the present-day Himalayas supplied sediment to the distal Bengal Fan since at least $17 \mathrm{Ma}$.
\end{abstract}

\section{INTRODUCTION}

\section{Objectives}

Fission-track analysis of detrital apatites recovered from Ocean Drilling Program (ODP) Leg 116 Sites 717 and 718 cores is used to: (1) constrain the thermal history of sediments overlying a region of deformed oceanic crust characterized by anomalous heat flow, and (2) characterize the thermotectonic history of the source terrane(s) from which the sediments originated.

A detailed heat-flow survey of the Leg 116 sites showed that heat flow over kilometer-scale distances in the vicinity of Site 718 ranged from 44 to $166 \mathrm{~mW} / \mathrm{m}^{2}$, providing strong evidence for upward migration of heat-carrying pore fluids (Cochran, Stow et al., 1989). Local convective heat transfer is also suggested by nonlinear temperature-depth profiles from other anomalous heat-flow areas in the central Indian Ocean (Geller et al., 1983). However, the heat source is unknown at this time. Anomalous heat flow in areas of the central Indian Ocean may be a consequence of lithospheric deformation evidenced by folding and faulting of the oceanic crust and overlying sediments (Weissel et al., 1980; Geller et al., 1983).

\footnotetext{
${ }^{1}$ Cochran, J. R., Stow, D.A.V., et al., 1990. Proc. ODP, Sci. Results, 116: College Station, TX (Ocean Drilling Program).

${ }^{2}$ Department of Geological Sciences, The University of Texas at Austin, Austin, TX 78713 , U.S.A.

${ }^{3}$ Department of Geology, Miami University, Oxford, OH 45056, U.S.A.
}

To elucidate the origin of these heat-flow anomalies, Site 718 was drilled to collect downhole temperature, geochemical, and sediment physical property data.

The primary objective of this study is to constrain the thermal evolution of sediments recovered from Site 717 and 718 holes using apatite fission-track analysis. The age of oceanic crust in the vicinity of Leg 116 sites is estimated to be about $80 \mathrm{Ma}$ (Norton and Sclater, 1979). The theoretical heat flow for $80 \mathrm{Ma}$ crust is about $55 \mathrm{~mW} / \mathrm{m}^{2}$ (Parsons and Sclater, 1977). For steady-state conduction and a mean sediment thermal conductivity of $1.6 \mathrm{~W} /{ }^{\circ} \mathrm{C} \mathrm{m}$, a geothermal gradient on the order of $35^{\circ} \mathrm{C} / \mathrm{km}$ is required to maintain this heat flow through the seafloor. For a $35^{\circ} \mathrm{C} / \mathrm{km}$ gradient and heating durations less than $17 \mathrm{Ma}$ (the age of oldest sediment recovered from Leg 116 holes), the upper kilometer of sediment would not attain thermal conditions capable of appreciable shortening of fission tracks in apatite. Shortening of fission tracks that could unambiguously be attributed to post-depositional thermal conditions would, therefore, provide evidence for additional heating by some mechanism other than conduction.

The second objective of this study is to use apatite fissiontrack ages to provide information on distal Bengal Fan source areas. Combined, drilling at Sites 717 and 718 yielded $1470 \mathrm{~m}$ of distal Bengal Fan stratigraphy that records a near continuous history of sedimentation over the past $17 \mathrm{Ma}$ (Cochran, Stow et al., 1989). To the extent that the Bengal Fan records the unroofing of the active Himalayan orogeny, apatite fission- 
track ages from these two sites provide a means of evaluating source-area denundation rates and the duration of time spent in transport by sediment deposited along the distal fan.

\section{Apatite Fission-Track Analysis}

Apatite fission-track analysis is a thermochronometric method that utilizes the annealing susceptibility of damage zones at low temperatures in this mineral to derive thermal history information. The spontaneous fission of trace amounts of ${ }^{238} \mathrm{U}$ in uranium-bearing minerals such as apatite produces two highly energetic fission fragments that create a linear trail of atomic defects (fission tracks) through the crystal lattice of these minerals (Fleischer et al., 1975). As the spontaneous fission rate of ${ }^{238} \mathrm{U}$ is statistically constant, the density of fission tracks in a mineral is a function of its uranium concentration and fission-track age. Fission-track ages record the minimum elapsed time during which tracks now present in the mineral have accumulated. Fission tracks in apatite anneal (shorten) at temperatures ranging from about $100^{\circ} \mathrm{C}$ to $400^{\circ} \mathrm{C}$ over short-term $(<1 \mathrm{yr})$, laboratory time scales (Laslett et al., 1987). For most geologic situations, partial annealing of fission tracks in apatite occurs over a temperature range of $20^{\circ} \mathrm{C}$ to $150^{\circ} \mathrm{C}$ based on empirical data from drill core samples with well-constrained thermal histories (Gleadow and Duddy, 1981; Naeser, 1981). Naeser's (1981) data indicate that complete track annealing occurs over a temperature range of about $105^{\circ} \mathrm{C}$ to $150^{\circ} \mathrm{C}$ for heating durations of $10^{8}$ to $10^{5} \mathrm{yr}$, respectively.
Apatite fission-track analysis involves both the determination of fission-track ages and the measurement of confined fission-track lengths. For samples that have cooled rapidly through the zone of partial track stability, and have remained below the zone of partial track stability since cooling, the fission-track age is a minimum estimate of the time since the apatite passed through its closure temperature (Dodson, 1973). However, due to natural geologic heating, apatite fission-track ages may not correspond to any geologic "event." Information about the cooling history, such as cooling rate or post-cooling thermal pulses, is provided by the mean track length and the track-length distribution (Crowley, 1985; Gleadow et al., 1986; Duddy et al., 1988). In this study, variations in fission-track ages and track-length distributions with depth are used to constrain the post-depositional thermal histories at Sites 717 and 718 .

\section{METHODS}

\section{Sampling Procedure and Preparation}

Samples from Leg 116, Site 717 and 718 holes, are used in this study. Samples were collected from the basal part of gray, fine-grained, sand-mud turbidite beds (Facies 1 of Cochran, Stow et al., 1989). Ten to fifteen, $10-$ to $20-\mathrm{cm}^{3}$ samples were combined over 70 - to 120 -m intervals starting from the base of each hole to provide sufficient material for analysis (Appendix A). A total of 14 composite samples, seven from each site, were collected (Fig. 1). Composite samples are denoted by the last digit of the hole $(7=$ hole at Site $717 ; 8=$ hole at Site 718)

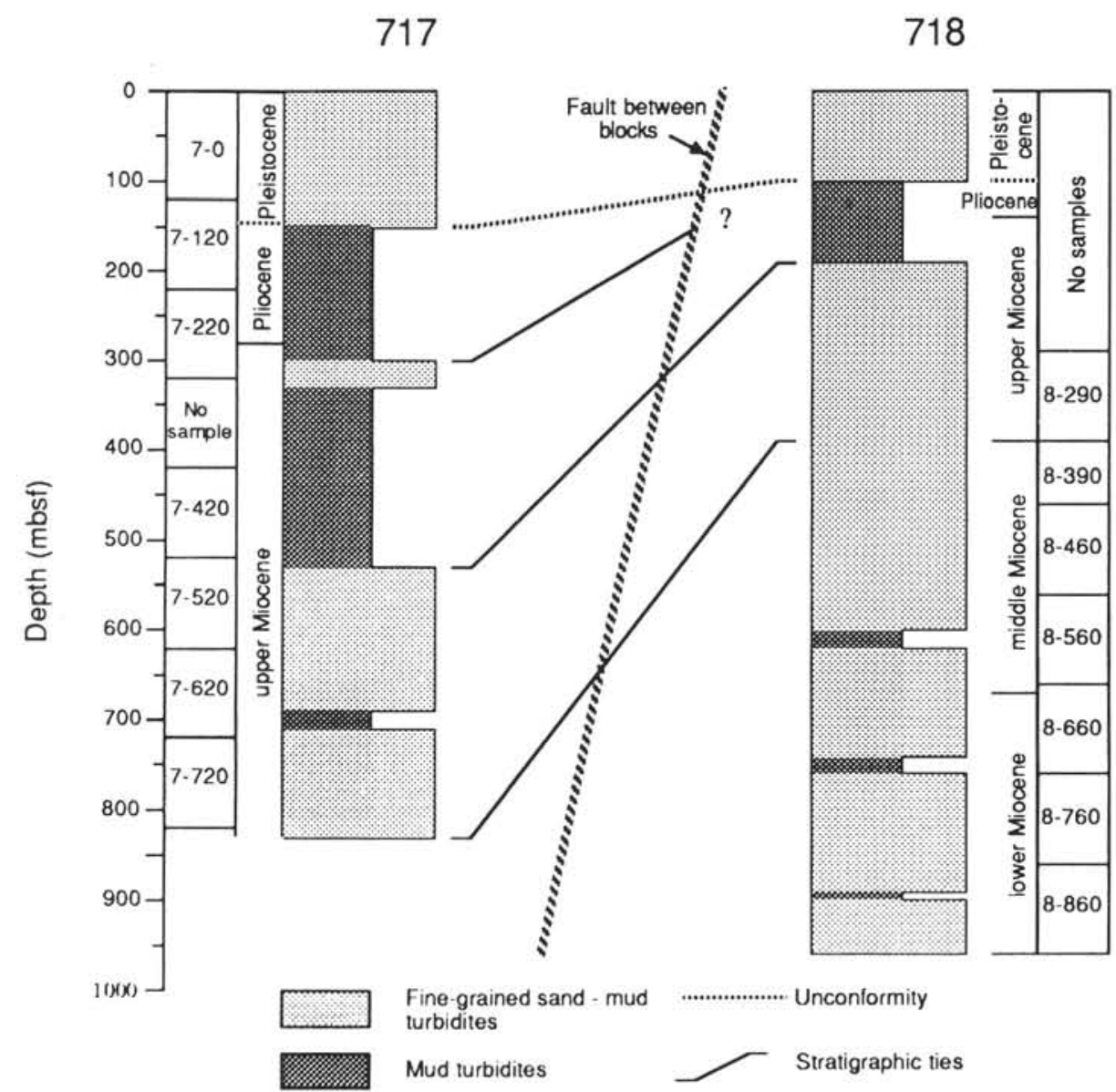

Figure 1. Generalized stratigraphic columns for holes at Sites 717 and 718 showing the sampled intervals for composite apatite samples ( $\mathrm{mbsf}=$ meters below seafloor). 
and the top of the collection interval in mbsf. For example, sample 7-660 is from sediment recovered at Site 717 and contains apatites from the 660 to 760 mbsf interval (Fig. 1, Table 1). Samples were wet-sieved to concentrate the fraction $>63 \mu \mathrm{m}$. Apatite grains were further concentrated using standard heavy-liquid and magnetic-separation techniques. Apatite separates from each sample were split into two aliquots (one for track-length measurements and one for age determinations) and mounted in epoxy. The mounts were then ground with abrasives to expose internal grain surfaces, and polished using $0.3-\mu \mathrm{m}$ aluminum oxide on a vibrating lap. Both mounts were etched in $7 \% \mathrm{HNO}_{3}(1.6 \mathrm{M})$ at $20^{\circ} \mathrm{C}$ for 40 $\mathrm{s}$ to reveal spontaneous tracks.

\section{Analytical Procedures}

One set of mounts was dated by the external detector method. These mounts were covered with low-uranium muscovite sheets and irradiated at the Texas A\&M University reactor facility at a nominal thermal neutron fluence of $1 \times 10^{16}$ neutrons $/ \mathrm{cm}^{2}$. Neutron fluences were monitored using National Bureau of Standards (NBS) SRM 612 glasses located at the middle and ends of the reactor tubes. After irradiation, muscovite covers on grain mounts were etched in $48 \% \mathrm{HF}$ for $15 \mathrm{~min}$ at $25^{\circ} \mathrm{C}$ to reveal induced tracks. Muscovite covers on NBS glasses were etched in $48 \%$ HF for $45 \mathrm{~min}$ at $25^{\circ} \mathrm{C}$. Muscovite covers on NBS glasses were counted with a $40 \times$ dry objective at a total magnification of $750 \times$. Spontaneous and induced track counts were made using a $100 \times$ oil-immersion objective at a total magnification of $1875 \times$.

Ages of individual apatite grains (Appendix B) were calculated using a zeta calibration (Hurford and Green, 1982, 1983) employing the Durango apatite (Naeser and Fleischer, 1975) as the age standard. A zeta calibration factor (Hurford and Green, 1983) for the age equation (Appendix B) was established for each of nine runs of the Durango apatite of known age (30.6 $\pm 0.6 \mathrm{Ma}$; Naeser and Fleischer, 1975). A weightedmean of these zeta determinations of $322 \pm 20 \mathrm{yr} /\left(\operatorname{tracks} \cdot \mathrm{cm}^{-2}\right)$ was then used to calculate fission-track ages. The error associated with this zeta determination is the standard error of the mean at the $95 \%$ confidence interval calculated by propagating Poisson errors for fossil track counts in the age standard, induced track counts in the mica detectors, and track counts in the fluence monitors, as well as the uncertainty in the age of the standard.

To reduce the possibility of bias in individual age determinations, the first 30 countable grains encountered in the mounts were dated. Countable grains were defined as those (1) oriented with their $c$-axes parallel or subparallel to the polished mount surface and (2) devoid of numerous defects (cracks, inclusions and/or dislocations). A key point in this procedure is that grains with low track densities were not avoided if otherwise appropriate for counting. Ages reported in the text and figures are mean (pooled) ages. Uncertainties in individual and mean fission-track ages were calculated by propagating Poisson errors for fossil track counts, induced track counts, and track counts in the fluence monitors, as well as systematic errors arising from uncertainties in the zeta calibration factor. Uncertainties in ages given in the text and figures represent the standard error of the mean at the $95 \%$ confidence interval.

The lengths of horizontal, confined spontaneous tracks in prismatic sections from the second, unirradiated set of mounts were measured with the oil-immersion lens at $1875 \times$ using a drawing tube and digitizing pad. For samples containing grains with sufficient track densities, the lengths of 50 confined, horizontal tracks were measured from the set of unirradiated mounts. Due to uphole decreases in spontaneous track density, fewer confined track-length measurements are available for samples with a depositional age of less then 10 $\mathrm{Ma}$ (Table 1). Uncertainties in sample mean track length also represent the standard error of the mean at the $95 \%$ confidence interval.

\section{RESULTS}

\section{Confined Track Lengths}

Mean lengths of horizontal, confined spontaneous tracks from Site 717 samples are identical, within error, and range from $14.4 \pm 0.5$ to $14.8 \pm 0.3 \mu \mathrm{m}$ (Fig. 2A). These mean lengths are about $10 \%$ shorter than mean lengths of unannealed, induced tracks in apatite, which are about $16.3 \mu \mathrm{m}$ (Gleadow et al., 1986). Mean confined track lengths from the upper part of the section at Site 718 (290-560 mbsf) are also identical within error (Fig. 2B), and they are statistically indistinguishable from Site 717 sample mean lengths (Table 1).

Table 1. Data summary for samples from holes at Sites 717 and 718.

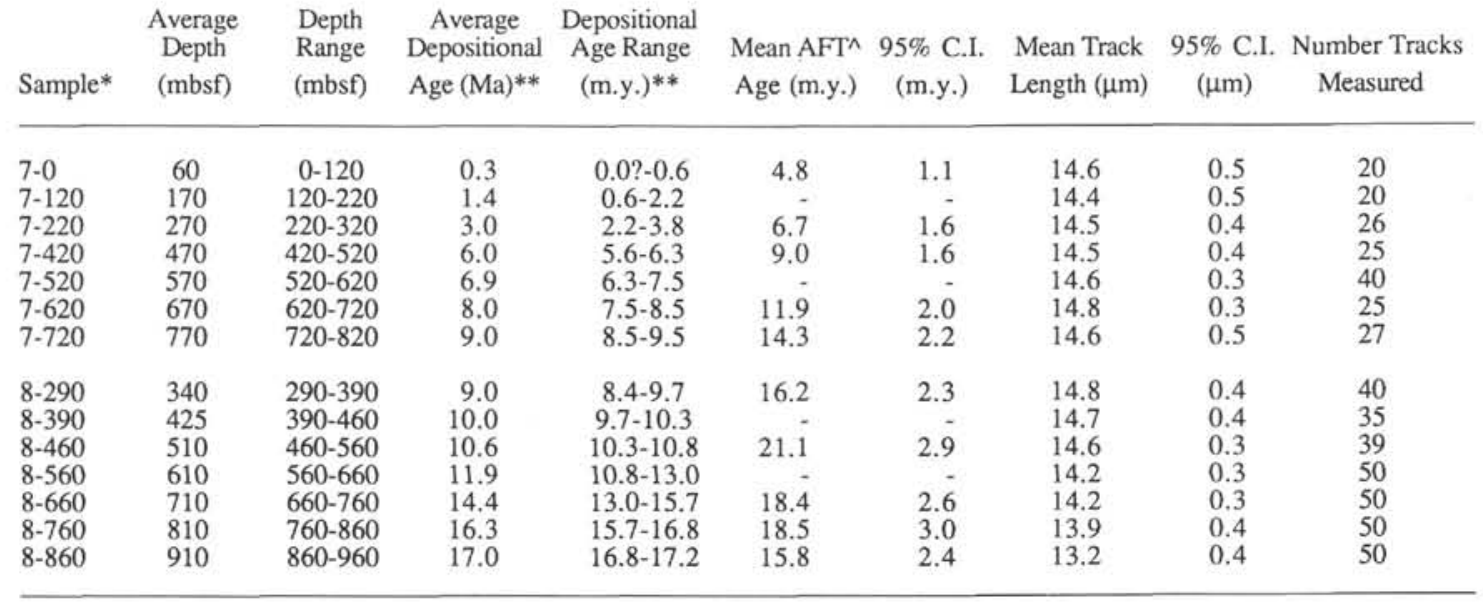

* First digit of sample number corresponds to last digit of hole number $(7=$ Site $717,8=$ Site 718$)$.

** Based on linear interpolation between biostratigraphic age assignments (Cochran, Stow et al., 1989).

$\wedge$ AFT - apatite fission-track. 

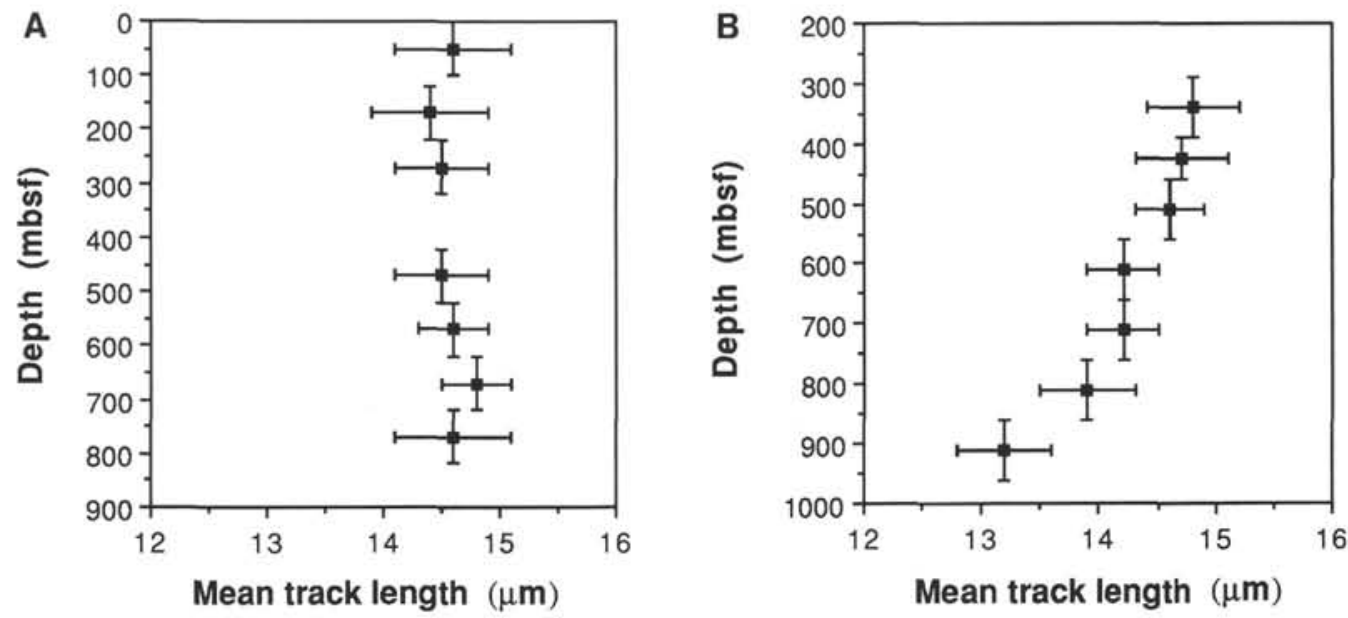

Figure 2. Downhole plots of mean track length for A. Site 717 and B. Site 718 . The vertical bars indicate the depth intervals of composite apatite samples. The horizontal bars are the standard error of the mean at the $95 \%$ confidence interval.

Mean confined track lengths decrease from $14.2 \pm 0.3 \mu \mathrm{m}$ below 560 mbsf to $13.2 \pm 0.4 \mu \mathrm{m}$ at the base of the hole (Fig. 2B). Apatites from the lowermost sample ( $860-960 \mathrm{mbsf}$ ) have a mean confined track length that is $20 \%$ shorter than that observed for unannealed induced fission tracks in apatite. Track-length distributions for individual samples from both sites are unimodal with one sigma standard deviations ranging from 0.9 to $1.4 \mu \mathrm{m}$ (Fig. 3).

\section{Fission-Track Ages}

Mean fission-track ages from Site 717 samples increase monotonically from $4.8 \pm 1.1 \mathrm{Ma}$ at the top of the hole to 14.3 $\pm 2.2 \mathrm{Ma}$ at the base (Fig. 4A). These ages are on the order of 3 to $5 \mathrm{~m}$.y. older than the sediment depositional ages (Fig. 4A). Mean fission-track ages for the two dated samples in the upper parts of holes at Site 718 increase with depth (Fig. 4B). The uppermost sample from Site $718(8-290)$ and lowermost sample from Site 717 (7-720) are derived from equivalent stratigraphic intervals (Fig. 1). These samples give mean fission-track ages of $16.2 \pm 2.3 \mathrm{Ma}$ and $14.3 \pm 2.2 \mathrm{Ma}$, respectively, and provide a check on the consistency of the data. Mean fission-track ages below 560 mbsf at Site 718 show an overall decrease in age with depth (Fig. 4B). The lowermost sample (8-860) has a mean fission-track age that is less than or equal to the average depositional age (Fig. 4B). Although these samples are composed of detrital grains, histograms of single grain ages are unimodal (Fig. 5). The variance of single-grain ages about the mean age is on the order of 10 to 40 m.y. for all samples except 8-460, which contains one outlier (Fig. 5).

\section{INTERPRETATION}

\section{Post-Depositional Thermal Histories of Sites 717 and 718}

Statistically constant mean track lengths that are only about $10 \%$ shorter than unannealed, induced track lengths observed in samples from Site 717 (Fig. 2A), coupled with the monotonic increase in mean fission-track ages with depth (Fig. $4 \mathrm{~A}$ ), indicate that these samples have existed at ambient or near-ambient temperatures since deposition. Studies of confined track lengths in apatites from a variety of geological settings indicate that, even in undisturbed volcanic rocks that cooled rapidly and were subjected to post-cooling temperatures of less than about $50^{\circ} \mathrm{C}$, spontaneous track lengths are always shorter than induced track lengths (Gleadow et al., 1986). These observations indicate that fission-track lengths in apatite are unstable even at ambient temperatures (Green, $1980,1988)$. Hence, the $10 \%$ shortening observed in Site 717 samples may be explained in large part by their annealing at ambient temperatures.

The systematic decrease in mean track length and age with depth below 560 mbsf at Site 718 (Figs. 2B and 4B) indicates post-depositional shortening of tracks has occurred over this interval. Recent laboratory annealing studies of apatite confirm earlier observations suggesting that increased chlorine content in the anion site corresponds to an increased resistance to track shortening at any given temperature (Green et al., 1985; Crowley and Cameron, unpubl. data). Electron microprobe-derived compositional data on apatites from Site 717 and 718 samples (Appendix C) indicate that apatite chlorine content does not vary appreciably between samples. Thus, it is unlikely that the observed downhole shortening of track lengths is related to differences in apatite chemistry. Of the approximately $20 \%$ total shortening of mean track length observed in sample 8-860 from the base of the recovered section at Site 718 , we estimate that approximately $10 \%$ is due to annealing at ambient conditions (as discussed above) and the remaining $10 \%$ is due to post-depositional annealing at elevated temperatures.

To constrain time-temperature conditions that could produce the $20 \%$ total track-length shortening observed at the base of the recovered section at Site 718, we use Laslett et al.'s (1987) extrapolation of their experimental track-length annealing studies on unannealed induced fission tracks in Durango apatite. There are several difficulties with this approach. First, uncertainties regarding modeling of annealing data are compounded when they are extrapolated several orders of magnitude to geologic time scales (Laslett et al., 1987). Second, annealing resistance in apatite is known to vary with apatite composition, with chlorine varieties being most resistant (Green et al., 1985; Crowley and Cameron, unpubl. data). Compositional data indicate that most apatites analyzed in this study are F-OH apatites (chlorine atoms per 13 oxygens $<0.03$ ), whereas the Durango apatite is a $\mathrm{F}-\mathrm{Cl}$ apatite (chlorine atoms per 13 oxygens $=0.08$; Young et al., 1969). Thus, extrapolation of track-length annealing data from Durango apatite may overestimate temperatures required to produce an equivalent amount of fission-track shortening in these samples. Finally, Laslett et al. (1987) investigated annealing for isothermal conditions, whereas variable temperature 


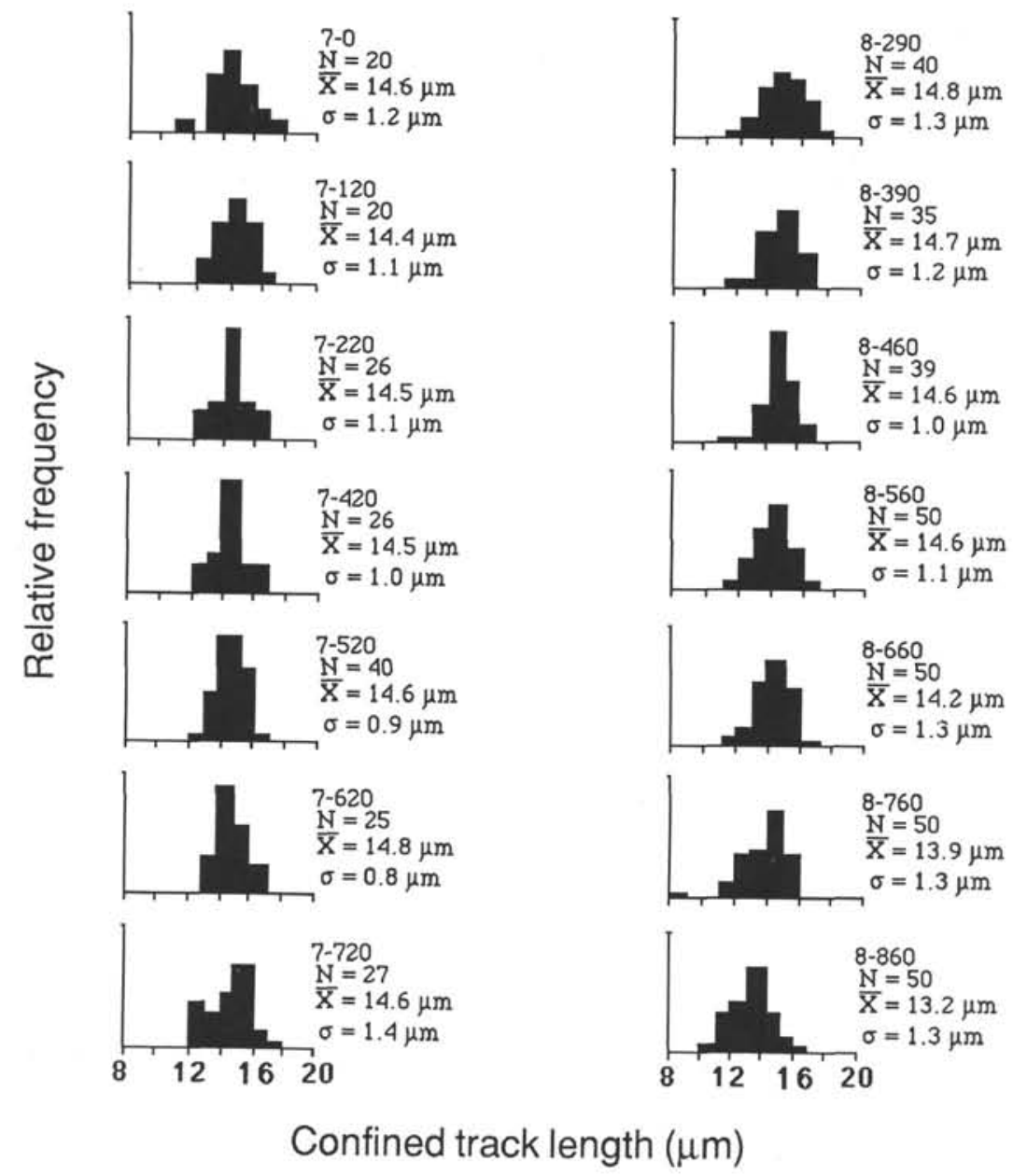

Figure 3. Histograms of confined track-length measurements over 1.0- $\mu \mathrm{m}$ intervals. Sample number, number of track lengths measured $(\mathrm{N})$, mean track length $(\overline{\mathrm{x}})$, and one-sigma standard deviation $(\sigma)$ are given for each plot.
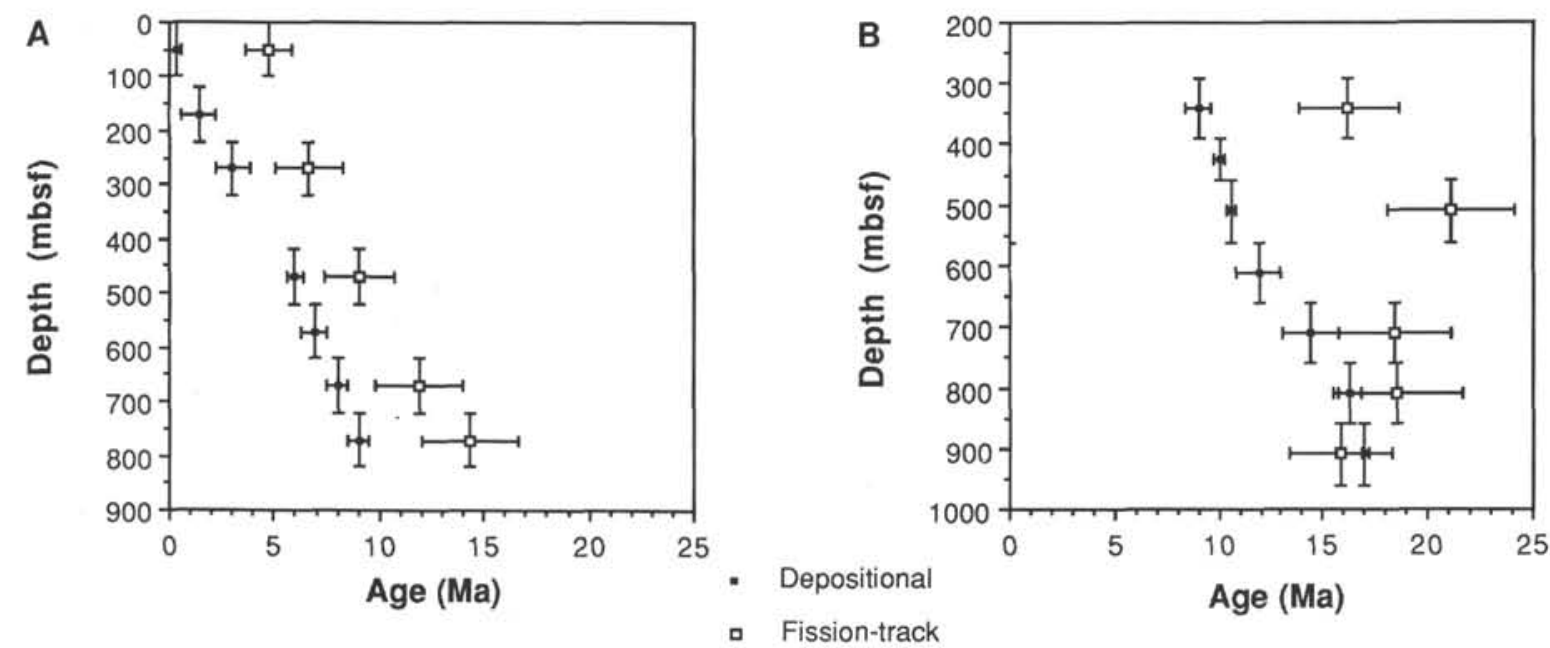

Figure 4. Downhole plots of sample average depositional ages and mean fission-track ages for A. Site 717 and B. Site 718 . The vertical bars indicate the depth intervals of composite apatite samples. The horizontal bars on depositional ages give the range of depositional ages for samples. The horizontal bars on mean fission-track ages are the standard error of the mean at the $95 \%$ confidence interval. 


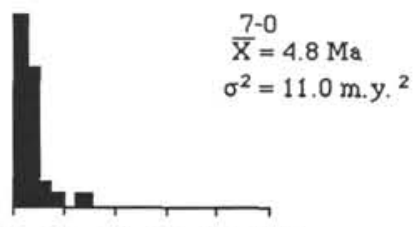

020406080100
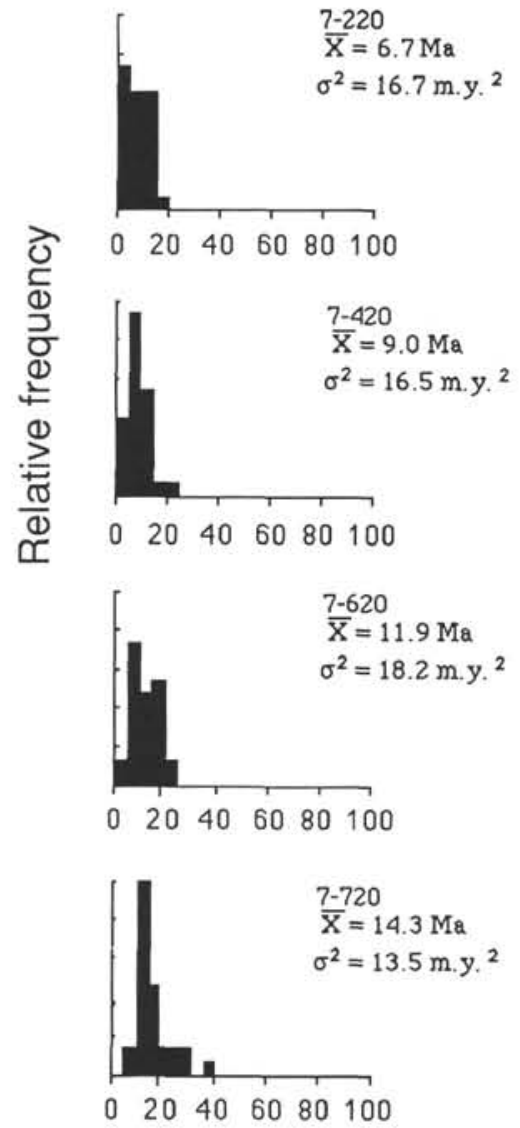
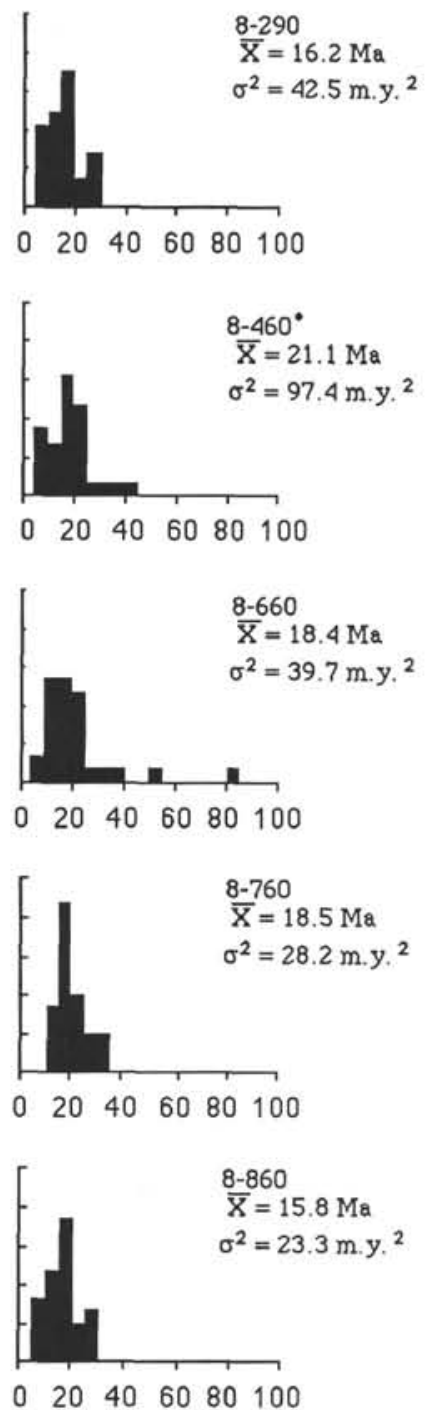

Fission-track age (Ma)

Figure 5. Histograms of fission-track ages for dated samples over 5-m.y. intervals. Sample number, mean age $(\overline{\mathrm{x}})$, and variance $\left(\sigma^{2}\right)$ of individual ages about the mean age are given for each plot. *-one grain with an age of $190.3 \pm 79.0 \mathrm{Ma}$ plots off the scale of the graph. Note that single-grain ages and their associated uncertainties are about the same order of magnitude (Appendix B).

annealing is expected for geologic settings. With these limitations in mind, we use Laslett et al.'s (1987) preferred fanning model to estimate that isothermal time-temperature conditions capable of producing a track-length reduction from $10 \%$ to $20 \%$ in the lowermost sample from Site 718 range from $50^{\circ}$ to $55^{\circ} \mathrm{C}$, for durations ranging from $17 \mathrm{~m} . \mathrm{y}$. (since deposition) to $7.5 \mathrm{~m} . \mathrm{y}$. (since the onset of faulting), respectively (Fig. 6).

Sediments at the base of the drilled section at Site 718 have been within about $100 \mathrm{~m}$ of their present depth below seafloor since the onset of deformation $(7 \mathrm{Ma})$. For a predicted conductive heat flow of $55 \mathrm{~mW} / \mathrm{m}^{2}$ for the approximately 80 -m.y.-old crust beneath Leg 116 sites (Parsons and Sclater, 1977; Norton and Sclater, 1979), and average, measured, sediment thermal conductivities of $1.3 \mathrm{~W} /{ }^{\circ} \mathrm{C} \mathrm{m}$ above $200 \mathrm{mbsf}$ and $1.9 \mathrm{~W} /{ }^{\circ} \mathrm{C}$ m below $200 \mathrm{mbsf}$ (Cochran, Stow et al., 1989), a present-day temperature of $33^{\circ} \mathrm{C}$ is predicted at a depth of 960 mbsf at Site 718 for purely conductive heat transfer assuming steady-state conditions. Apatite fission-track data presented here provide evidence for temperatures greater than $50^{\circ} \mathrm{C}$ at depths of 860 to 960 mbsf at Site 718 , indicating that conductive heat transfer due to lithospheric cooling cannot account for the observed track shortening in samples below 560 mbsf at Site 718 .

Variable and anomalously high heat-flow values in the vicinity of Site 718 suggest advection of heat via upward migration of pore fluids (Cochran, Stow et al., 1989). Shortening of fission tracks in apatite at elevated temperatures below 560 mbsf at Site 718 implies that convective heat transfer, as evidenced by seafloor heat-flow data in the vicinity of Site 718 , is not a transient phenomenon. No evidence is found from either downhole temperature or fission-track data for hydrothermal activity near Site 717 , located just $7 \mathrm{~km}$ north of Site 718 on an adjacent fault block. The fault separating these two blocks is located approximately $1.5 \mathrm{~km}$ north of Site 718 and has been active since $7.5 \mathrm{Ma}$ (Cochran, Stow et al., 1989). The heat flow conclusions and fission-track 
Temperature $\left({ }^{\circ} \mathrm{C}\right)$

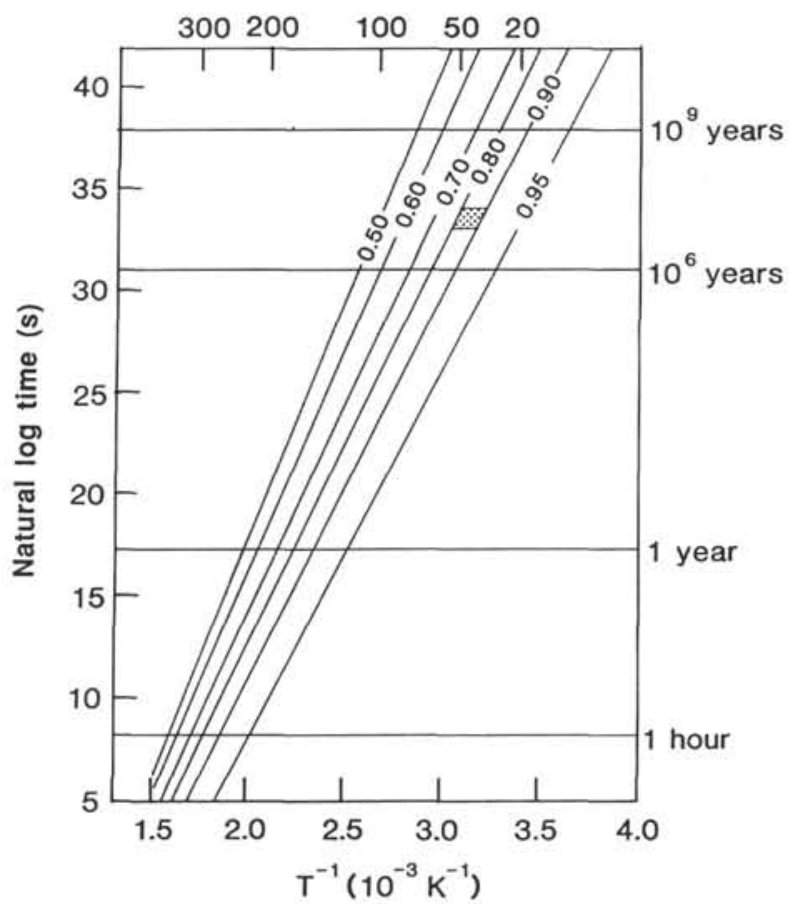

Figure 6. Fanning Arrehnius diagram for experimental apatite fission-track-length annealing data of Laslett et al. (1987) extrapolated to geologic time scales. The shaded region indicates the range of isothermal time-temperature conditions capable of producing track shortening observed in the lowermost sample (8-860) from Site 718 .

observations from Site 718 suggest that this fault provides a conduit for upward migration of heated pore fluids.

\section{Bengal Fan Source Areas}

A first-order observation from Figure 4 is that mean fission-track ages of samples from Sites 717 and 718 do not deviate from the average depositional age of these apatites by more than about $10 \mathrm{~m} . \mathrm{y}$. Because Durango apatite, used in the zeta calibration for calculating fission-track ages, has a mean track length that is $9 \%$ shorter than unannealed, induced tracks (Gleadow et al., 1986), we implicitly correct for equivalent amounts of track shortening in calculating fission-track ages for samples in this study. For samples from Site 717 and the upper part of Site 718 , which have experienced $\leq 10 \%$ track shortening, the last significant cooling event occurred within about 3 to $10.5 \mathrm{~m}$.y. prior to deposition. Cerveny et al. (1988) obtained very similar results in their fission-track study of detrital zircons from Siwalik Group sandstones and Indus River sands in northern Pakistan. They found that these fluvial sands and sandstones contain zircons that are only $1-5 \mathrm{~m} . \mathrm{y}$. older than sample depositional ages $(\leq 18 \mathrm{Ma})$.

Continuous volcanism throughout the Neogene in the source area(s) could explain such young fission-track ages in detrital apatites from the distal Bengal Fan. However, Neogene volcanics in possible source areas on the Indo-Eurasia continent are really restricted (Gansser, 1964). The most extensive area of young volcanism appears to be the Gangdese (Trans-Himalayan) Belt, southern Tibet, where local activity has been placed around 10-15 Ma (Coulon et al., 1986). Crystallization ages of exposed batholiths in the Gandese Belt range from 110 to $40 \mathrm{Ma}$ (Schrärer et al., 1984; Xu et al., 1985), and the timing of major volcanic activity in this region is placed around 50-60 Ma (Coulon et al., 1986). The timing of this magmatic activity is too early to account for the apatite ages found in samples from Sites 717 and 718. A more likely explanation for these ages is that they record the timing of rock uplift in the source area(s) through the zone of partial track stability for apatite.

A detrital apatite fission-track age represents the elapsed time during which tracks have accumulated; the age records contributions from its uplift, transport, and post-depositional histories. In the case where no post-depositional annealing has affected the age, the observed age, $t_{\mathrm{obs}}$, is given by:

$$
t_{\mathrm{obs}}=t_{u}+t_{\mathrm{t}}+t_{\mathrm{s}}
$$

where: $t_{\mathrm{u}}=$ elapsed time required for apatite to pass through its effective closure temperature $\left(110 \pm 10^{\circ} \mathrm{C}\right)$ and reach the surface (a function of uplift and erosion), $t_{t}=$ elapsed time spent in transport, and $t_{\mathrm{s}}=$ elapsed time since final deposition (Zeitler et al., 1986). The elapsed time since final deposition, $t_{\mathrm{s}}$, can be estimated from nannofossil biostratigraphy (Table 1 and Cochran, Stow et al., 1989). Because post-depositional track shortening is implicitly corrected for by using an age standard with a similar amount of track shortening for samples from Site 717 and Site 718 , taking the mean fission-track age for these samples to be $T_{\text {obs }}$ provides a minimum estimate of the timing of the last significant cooling event. If rates of erosion kept pace with rates of uplift, a reasonable first-order approximation, $t_{\mathrm{u}}$ can be interpreted as the elapsed uplift time. Therefore, the averaged combined time that apatites spent in uplift (after passing through their closure temperature) and transport for a given sample is estimated by $t_{\mathrm{obs}}-t_{s}$ (Fig. 7). If it is assumed that $t_{u}=0$, these time intervals also provide an upper limit on the sample-averaged sediment transport time, indicating that sediment spent no more than about $10 \mathrm{~m} . \mathrm{y}$. reaching the distal Bengal Fan after leaving their source areas. Similarly, taking transport time to be effectively instantaneous (setting $t_{\mathrm{t}}=0$ ) provides an estimate of maximum, sampleaveraged elapsed uplift time. Maximum, sample-averaged

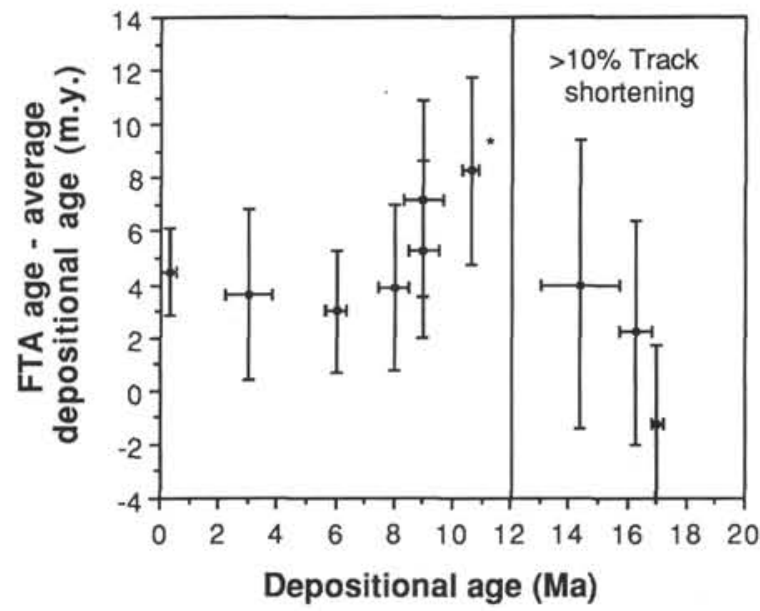

Figure 7. Mean fission-track age minus the average depositional age plotted against average depositional age (*-based on a mean age of $18.9 \pm 2.7 \mathrm{Ma}$ for sample 8-460 determined by not including the single-grain age of $190.3 \pm 79.0 \mathrm{Ma}$ ). Mean age minus average depositional age provides a sample-averaged estimate of the maximum duration of time spent in transport, as well as a sample-averaged estimate of the maximum duration of time required for apatite to reach the surface after passing through its effective closure temperature $\left(110^{\circ} \pm 10^{\circ} \mathrm{C}\right)$. See text for assumptions and derivation of estimates. 
elapsed uplift times determined in this manner range from 2 to $9 \mathrm{~m}$.y. for samples with $\leq 10 \%$ track shortening (Fig. 7).

These maximum, sample-averaged elapsed uplift times provide a basis for estimating source area denundation rates. Neglecting radiogenic heat production and assuming (1) a constant source-area geothermal gradient, (2) apatites passed upward through stationary isotherms (relative to the earth's surface), and (3) erosion rates approximated uplift rates, an estimate of the minimum, sample-averaged denundation rate $\left(d z / d t_{\min }\right)$ is given by:

$$
d z / d t_{\min }=\frac{T_{\mathrm{eff}}}{(d T / d z)\left(t_{\mathrm{umax}}\right)}
$$

where $T_{\text {eff }}=$ the effective closure temperature of the apatite fission-track system $\left(110^{\circ} \pm 10^{\circ} \mathrm{C}\right), d T / d z=$ the average geothermal gradient in the source area, and $t_{\text {umax }}=$ the maximum, sample-averaged uplift time as defined above. Taking $30^{\circ} \mathrm{C} / \mathrm{km}$ is an appropriate geothermal gradient for an orogenic terrane (Blackwell, 1971) gives sample-averaged, minimum denundation rates on the order of 0.5 to $1.5 \mathrm{~km} / \mathrm{m} . \mathrm{y}$. However, these estimates invalidate assumptions (1) and (2). Denundation rates approaching or exceeding about $300 \mathrm{~m} /$ m.y. will compress near-surface isotherms, causing a corresponding increase in geothermal gradients (Parrish, 1985; Koons, 1987). The above estimates would therefore overestimate true uplift rates. On the other hand, if we assume source area, upper-crustal geothermal gradients never exceeded $60^{\circ} \mathrm{C} / \mathrm{km}$, which we take as a reasonable upper limit, then these data still imply source-area denundation rates of $\geq 300$ $\mathrm{m} / \mathrm{m}$.y. for all samples. Zeitler et al. (1986) inferred similar unroofing rates for parts of the northern Pakistan Siwalik Group source areas from fission-track ages of detrital zircons contained in Siwalik Group sandstones.

\section{CONCLUSIONS}

Fission-track ages and confined track-length measurements from detrital apatites recovered from Leg 116 cores obtained from Sites 717 and 718 constrain the thermal history of the sediments at these two sites and the thermotectonic histories of their source areas. Statistically-constant mean track lengths observed from Site 717 samples suggest that downhole temperatures have never exceeded about $50^{\circ} \mathrm{C}$. A decrease in mean track length $(14.6 \pm 0.3$ to $13.2 \pm 0.4 \mu \mathrm{m})$ and mean fission-track age $(21.1 \pm 2.9$ to $15.8 \pm 2.4 \mathrm{Ma})$ with depth from 560 to $960 \mathrm{mbsf}$ at Site 718 indicates post-depositional shortening of fission tracks at elevated temperatures below $560 \mathrm{mbsf}$. The total amount of track shortening is estimated to be approximately $20 \%$ for the lowermost sample (860- to 960 -msbf interval) at Site 718 . Based on extrapolation of published laboratory track-length annealing experiments, isothermal time-temperature condition extremes that could produce this degree of shortening are estimated to range from $50^{\circ} \mathrm{C}$ for $17 \mathrm{~m} . \mathrm{y}$. (since deposition) to $55^{\circ} \mathrm{C}$ for 7.5 m.y. (since the onset of faulting). These estimates argue against conductive heating due to lithospheric cooling as the only mechanism for heating and suggest an additional heat source and/or heat transport mechanism near Site 718.

Dated samples have mean ages that are between 0 and 10 m.y. older than depositional ages. These young ages indicate that sediment transport from source areas required no more than about $10 \mathrm{~m}$.y. Such young cooling ages for detrital apatites also imply source areas characterized by high uplift and erosion rates ( $\geq 300 \mathrm{M} / \mathrm{m} . \mathrm{y}$.). These denundation rates suggest that source areas similar to parts of the present-day Himalayas supplied sediment to the distal Bengal Fan since at least $17 \mathrm{Ma}$.

\section{ACKNOWLEDGMENTS}

This investigation was stimulated by a seminar taught by Mark Cloos. We also thank John Krohn of Texas A\&M University for conducting sample irradiations, Dwight Deuring of Southern Methodist University for assistance in running some of the electron microprobe analyses, as well as the U.S. Department of Energy for support provided through the ReactorSharing Program at Texas A\&M University. Critical reviews by Mark Cloos and Charles W. Naeser improved this manuscript. Funding for this study was provided by a JOI/USSAC Ocean Drilling Program Fellowship and a University of Texas at Austin Institute for Geophysics Ewing-Worzel Fellowship to Corrigan.

\section{REFERENCES}

Bevington, P. R., 1969. Data reduction and error analysis for the physical sciences: New York (McGraw-Hill).

Blackwell, D. D., 1971. The thermal structure of the continental crust. In Heacock, J. G. (Ed.), The Structure and Physical Properties of the Earth's Crust: Am. Geophys. Union Geophysical Monographs, 14:169-184.

Cerveny, P. F., Naeser, N. D., Zeitler, P. K., Naeser, C. W., and Johnson, N. M., 1988. History of uplift and relief of the Himalaya during the past 18 million years: Evidence from fission-track ages of detrital zircons from sandstones of the Siwalik Group. In Kleinspehn, K. L., and Paola C. (Eds.), New Perspectives in Basin Analysis: New York (Springer-Veriag), 43-61.

Cochran, J. R, Stow, D.A.V., et al., 1989. Proc. ODP, Init. Repts., 116: College Station, TX (Ocean Drilling Program).

Coulon, C., Maluski, H., Bollinger, C., and Wang, S., 1986. Mesozoic and Cenozoic volcanics from central and southern Tibet: ${ }^{39} \mathrm{Ar}-{ }^{40} \mathrm{Ar}$ dating, petrological characteristics, and geodynamical significance. Earth Planet.Sci. Lett., 79:281-302.

Crowley, K. D., 1985. Thermal significance of fission-track length distributions. Nucl. Tracks, 10:311-322.

Dodson, M., 1973. Closure temperature in cooling geochronological and petrological systems. Contrib. Mineral. Petrol., 40:259-274.

Duddy, I. R., Green, P. F., and Laslett, G. M., 1988. Thermal annealing of fission tracks in apatite-3. Variable temperature behavior. Chem. Geol. (lsotope Geoscience Section), 73:25-38.

Fleischer, R. L., Price, P. B., and Walker, R. M., 1975. Nuclear Tracks in Solids: Berkeley (University of California Press). Galbraith, R., 1980. On statistical models for fission track counts. Math. Geol., 13:471-478.

Gansser, A., 1964. The Geology of the Himalayas: New York (Wiley-Interscience).

Geller, C. A., Weissel, J. K., and Anderson, R. N., 1983. Heat transfer and intraplate deformation in the central Indian Ocean. $J$. Geophys. Res., 88:1018-1032.

Gleadow, A.J.W., and Duddy, I. R., 1981. A natural long-term annealing experiment for apatite. Nucl. Tracks, 5:169-174.

Gleadow, A.J.W., Duddy, I. R., Green, P. F., and Lovering, J. F., 1986. Confined track lengths in apatite-a diagnostic tool for thermal history analysis. Contrib. Mineral. Petrol., 94:405-415.

Green, P. F., 1980. On the cause of shortening of spontaneous fission tracks in certain minerals. Nucl. Tracks, 4:91-100.

Green, P. F., 1981. A new look at statistics in fission-track dating. Nucl. Tracks, 5:77-86.

Green, P. F., 1988. The relationship between track shortening and fission track age reduction in apatite: combined influences of inherent instability, annealing anisotropy, length bias and system calibration. Earth Planet. Sci. Lett., 89:335-352.

Green, P. F., Duddy, I. R., Gleadow, A.J.W., Tingate, P. R., and Laslett, G. M., 1985. Fission-track annealing in apatite: track length measurements and the form of the Arrhenius plot. Nucl. Tracks, 10:323-328.

Hurford, A. J., and Green, P. F., 1982. A user's guide to fission-track dating calibration. Earth Planet. Sci. Lett., 59:343-354.

Hurford, A. J., and Green, P. F., 1983. The zeta age calibration of fission track dating. Chem. Geol. (Isotope Geoscience Section), $1: 285-317$. 
Koons, P. O., 1987. Some thermal and mechanical consequences of rapid uplift: an example from the Southern Alps, New Zealand. Earth Planet. Sci, Lett., 86: 307-319.

Laslett, G. M., Green, P. F., Duddy, I. R., and Gleadow, A.J.W., 1987. Thermal annealing of fission tracks in apatite-2. a quantitative analysis. Chem. Geol., 65:1-15.

Naeser, C. W., 1981. The fading of fission tracks in the geologic environment-data from deep drill holes. Nucl. Tracks, 5:248-250 (abstract). Naeser, C. W., and Fleischer, R. L., 1975. Age of the apatite at Cerro de Mercado, Mexico: a problem for fission track annealing corrections. Geophys. Res. Lett., 2:67-70.

Norton, I. O., and Sclater, J. G., 1979. A model for the evolution of the Indian Ocean and the breakup with Gondwanaland. J. Geophys. Res., 84:6803-6830.

Parrish, R. R., 1985. Some cautions which should be exercised when interpreting fission-track and other dates with regard to uplift calculations Nucl. Tracks, 10:425.

Parsons, B. and Sclater, J. G., 1977. An analysis of variation of oceanic floor bathymetry and heat flow with age. J. Geophys. Res., 82:803-827.

Schrärer, U., Xu, R.-H., and Allégre, 1984. U-Pb geochronology of the Gandese (Transhimalaya) plutonism in the Lhasa-Xigaze region, Tibet. Earth Planet. Sci. Lett., 69:311-320.

Weissel, J. K., Anderson, R. N., and Geller, C. A., 1980. Deformation of the Indo-Australian Plate. Nature, 287:284-291.

Xu, R.-H., Schräer, U., and Allégre, 1985. Magmatism and metamorphism in the Lhasa block (Tibet). J. Geol., 93:41-57.

Young, E. J., Myers, A. T., Munson, E. L., and Conklin, N. M., 1969. Mineralogy and geochemistry of fluorapatite from Cerro de Mercado, Durango, Mexico. U.S. Geol. Surv. Prof. Pap., 650D:D84-D93

Zeitler, P. K., Johnson, N. M., Briggs, N. D., and Naeser, C. W., 1986. Uplift history of the NW Himalaya as recorded by fissiontrack ages on detrital Siwalik zircons. In Jiqing, H. (Ed.), Proc.
Symp. Mesozoic and Cenozoic Geol., (60th anniv. meet., Geol. Soc. China): Beijing (Geological Publishing House): 48:1-494.

Date of initial receipt: 24 February 1989

Date of acceptance: 3 January 1990

Ms 116B-118

\section{APPENDIX A}

\section{Sample Information}

Composite samples used in this study consist of six to ten, 10 - or $20-\mathrm{cm}^{3}$ shipboard core samples combined over $100-\mathrm{m}$ intervals (except 7-0 and 8-390 which were sampled over 120and $70-\mathrm{m}$ intervals, respectively) beginning at the bases of holes at Sites 717 and 718. Shipboard sampling of these intervals was aimed at uniform representation of the entire interval. However, core recovery and the distribution of units containing sand ultimately dictated sampling. Insufficient recovery and/or lack of fine-grained sand from the 320 to 420 mbsf interval at Site 717 and the 0- to 290-mbsf interval at Site 718 prevented collection of composite apatite samples from these intervals (Fig. 1).

A summary of the composite samples is provided in the following tables. The depositional age range shown in the AGE column is based on a linear interpolation of age as a function of depth between the age assignments based on nannofossil zones (Cochran, Stow, et al., 1989). Ages with an asterisk $\left(^{*}\right)$ denote interpolated ages.

\begin{tabular}{|c|c|c|c|c|c|c|c|c|}
\hline SAMPLE\# & SITE & SAMPLES & $\begin{array}{l}\text { DEPTH } \\
\text { (mbsl) }\end{array}$ & VOLUME (cc) & $\begin{array}{l}\text { INITIAL DRY } \\
\text { WEIGHT (g) }\end{array}$ & $\begin{array}{c}>63 \text { um } \\
\text { WEIGHT (g) }\end{array}$ & $\begin{array}{c}\text { NANNOFOSSIL } \\
\text { ZONE }\end{array}$ & $\begin{array}{c}\text { DEPOSITIONAL } \\
\text { AGE (Ma) }\end{array}$ \\
\hline \multirow[t]{12}{*}{$717-0$} & $717 \mathrm{~B}, \mathrm{C}$ & & $0-100$ & 190 & 300 & 172 & CN15-CN14a & $0 ?-0.56^{*}$ \\
\hline & $717 \mathrm{~B}$ & $2 \mathrm{H}-04-130-135$ & 9.80 & 20 & & & & \multirow[t]{11}{*}{$<0.5$} \\
\hline & $717 \mathrm{~B}$ & $2 \mathrm{H}-05-130-134$ & 11.30 & 20 & & & & \\
\hline & $717 \mathrm{C}$ & $2 \mathrm{H}-02-100-105$ & 16.00 & 20 & & & & \\
\hline & $717 \mathrm{C}$ & $4 \mathrm{X}-0 \mathrm{~S}-2-6$ & 31.52 & 20 & & & & \\
\hline & $717 \mathrm{C}$ & $5 X-02-28-32$ & 42.78 & 20 & & & & \\
\hline & $717 \mathrm{C}$ & $6 \mathrm{X}-02-31-33$ & 47.81 & 10 & & & & \\
\hline & $717 \mathrm{C}$ & $6 \mathrm{X}-02-35-37$ & 47.85 & 10 & & & & \\
\hline & $717 \mathrm{C}$ & $7 \mathrm{X}-\mathrm{CC}-20-24$ & 57.60 & 20 & & & & \\
\hline & $717 \mathrm{C}$ & $8 X-01-63-65$ & 65.63 & 10 & & & & \\
\hline & $717 \mathrm{C}$ & $10 X-C C-15-20$ & 76.15 & 20 & & & & \\
\hline & $717 \mathrm{C}$ & $12 X-C C-0-5$ & 93.50 & 20 & & & & \\
\hline \multirow[t]{9}{*}{$717-120$} & $717 \mathrm{C}$ & & $120-220$ & 150 & 240 & 130 & CN14-CN12 & $0.56^{*}-2.2$ \\
\hline & $717 \mathrm{C}$ & $16 \mathrm{X}-\mathrm{CC}-16-21$ & 123.46 & 20 & & & & \\
\hline & $717 \mathrm{C}$ & 18X-CC-PALEO & 131.63 & 10 & & & & \\
\hline & $717 \mathrm{C}$ & $18 \mathrm{X}-\mathrm{CC}-13-17$ & 131.63 & 20 & & & & \\
\hline & $717 \mathrm{C}$ & $19 X-1-76-80$ & 141.76 & 20 & & & & \\
\hline & $717 \mathrm{C}$ & $20 X-1-85-90$ & 151.35 & 20 & & & & \\
\hline & $717 \mathrm{C}$ & $22 X-4-144-149$ & 175.44 & 20 & & & & \\
\hline & $717 \mathrm{C}$ & $23 X-2-145-150$ & 181.95 & 20 & & & & \\
\hline & $717 \mathrm{C}$ & $26 X-4-97-102$ & 212.97 & 20 & & & & \\
\hline \multirow[t]{9}{*}{$717-220$} & $717 \mathrm{C}$ & & $220-320$ & 180 & 200 & 60 & $\mathrm{CN} 12 \mathrm{a}-\mathrm{CN} 11$ & $2.2-3.8^{*}$ \\
\hline & $717 \mathrm{C}$ & $33 \mathrm{X}-\mathrm{CC}-\mathrm{PALEO}$ & 283.60 & 30 & & & & \\
\hline & $717 \mathrm{C}$ & $33 \mathrm{X}-\mathrm{CC}-27-33$ & 283.60 & 20 & & & $=$ & \\
\hline & $717 \mathrm{C}$ & $34 X-1-83-88$ & 284.33 & 20 & & & & \\
\hline & $717 \mathrm{C}$ & $34 X-2-145-150$ & 286.45 & 20 & & & & \\
\hline & $717 \mathrm{C}$ & 36X-CC-PALEO & 312.10 & 30 & & & & \\
\hline & $717 \mathrm{C}$ & $36 \mathrm{X}-\mathrm{CC}-27-32$ & 312.10 & 20 & & & & \\
\hline & $717 \mathrm{C}$ & $37 X-2-106-111$ & 314.56 & 20 & & & & \\
\hline & $717 \mathrm{C}$ & $37 \mathrm{X}-\mathrm{CC}-26-31$ & 316.06 & 20 & & & & \\
\hline
\end{tabular}


Appendix A (continued).

\begin{tabular}{|c|c|c|c|c|c|c|c|c|}
\hline $717-420$ & $717 \mathrm{C}$ & & $420-520$ & 170 & 340 & 75 & CN9b-CN9 & $5.6-6.3^{*}$ \\
\hline & $717 \mathrm{C}$ & $51 X-2-82-87$ & 447.32 & 20 & & & & \\
\hline & $717 \mathrm{C}$ & $51 X-2-98-103$ & 447.48 & 20 & & & & \\
\hline & 717C & $53 X-1-100-120$ & 465.00 & 10 & & & & \\
\hline & $717 \mathrm{C}$ & $53 X-1-117-121$ & 465.17 & 20 & & & & \\
\hline & $717 \mathrm{C}$ & $57 X-4-80-85$ & 507.30 & 50 & & & & \\
\hline & $717 \mathrm{C}$ & $57 X-4-104-109$ & 507.54 & so & & & & \\
\hline \multirow[t]{13}{*}{$717-520$} & $717 \mathrm{C}$ & & $520-620$ & 210 & 410 & 135 & CN9-CN9 & $6.3^{*}-7.5^{*}$ \\
\hline & $717 \mathrm{C}$ & $60 X-3-61-63$ & 534.11 & 10 & & & & \\
\hline & $717 \mathrm{C}$ & $61 X-1-107-11$ & 541.07 & 20 & & & & \\
\hline & $717 \mathrm{C}$ & $62 X-1-15-19$ & 549.65 & 20 & & & & \\
\hline & $717 \mathrm{C}$ & $62 X-C C-6-10$ & 550.42 & 20 & & & & \\
\hline & $717 \mathrm{C}$ & $63 X-1-33-38$ & 559.33 & 20 & & & & \\
\hline & $717 \mathrm{C}$ & $64 X-3-146-151$ & 572.96 & 20 & & & & \\
\hline & $717 \mathrm{C}$ & $64 X-4-1-3$ & 573.01 & 10 & & & & \\
\hline & $717 \mathrm{C}$ & $67 X-1-108-112$ & 598.08 & 20 & & & & \\
\hline & $717 \mathrm{C}$ & $67 X-2-77-81$ & 599.27 & 20 & & & & \\
\hline & $717 \mathrm{C}$ & $68 X-4-145-150$ & $611-63$ & 20 & & & & \\
\hline & $717 \mathrm{C}$ & $69 \mathrm{X}-1-10-14$ & 616.10 & 10 & & & & \\
\hline & $717 \mathrm{C}$ & $69 X-1-14-19$ & 616.14 & 20 & & & & \\
\hline \multirow[t]{11}{*}{$717-620$} & $717 \mathrm{C}$ & & $620-720$ & 260 & 535 & 165 & CN9-CN8b & $7.5^{*}-8.5^{*}$ \\
\hline & $717 \mathrm{C}$ & $69 \mathrm{X}-\mathrm{CC}-21-26$ & 620.31 & 20 & & & & \\
\hline & $717 \mathrm{C}$ & $71 X-4-100-106$ & 640.50 & 40 & & & & \\
\hline & $717 \mathrm{C}$ & $71 X-5-90-95$ & 641.90 & 20 & & & & \\
\hline & $717 \mathrm{C}$ & $72 X-1-64-70$ & 645.14 & 40 & & & & \\
\hline & $717 \mathrm{C}$ & $74 X-1-94-100$ & 664.44 & 40 & & & & \\
\hline & $717 \mathrm{C}$ & $75 X-4-35-40$ & 677.85 & 20 & & & & \\
\hline & $717 \mathrm{C}$ & $75 \mathrm{X}-\mathrm{CC}-33-38$ & 678.30 & 20 & & & & \\
\hline & $717 \mathrm{C}$ & $76 X-3-83-88$ & 686.33 & 20 & & & & \\
\hline & $717 \mathrm{C}$ & $78 X-6-128-132$ & 710.20 & 20 & & & & \\
\hline & $717 \mathrm{C}$ & $79 X-3-61-66$ & 714.61 & 20 & & & & \\
\hline
\end{tabular}

\begin{tabular}{|c|c|c|c|c|c|c|c|c|}
\hline SAMPLE\# & SITE & SAMPLES & $\begin{array}{l}\text { DEPTH } \\
\text { (mbsl) }\end{array}$ & $\operatorname{VOLUME}(c c)$ & $\begin{array}{l}\text { INITIAL DRY } \\
\text { WEIGHT (g) }\end{array}$ & $\begin{array}{c}>63 \text { um } \\
\text { WEIGHT (g) }\end{array}$ & $\begin{array}{c}\text { NANNOFOSSI } \\
\text { ZONE }\end{array}$ & $\begin{array}{l}\text { EPOSITIONAL } \\
\text { AGE (Ma) }\end{array}$ \\
\hline \multirow{10}{*}{$717-720$} & $717 \mathrm{C}$ & & $720-820$ & 260 & 535 & 147 & CN8b-CN7? & $8.5^{*}-9.5$ \\
\hline & $717 \mathrm{C}$ & $80 X-03-39-45$ & 723.89 & 40 & & & $\mathrm{CN} 8 \mathrm{~b}$ & \\
\hline & $717 \mathrm{C}$ & 81 X-CC-24-28 & 731.12 & 20 & & & & \\
\hline & $717 \mathrm{C}$ & $82 X-01-29-35$ & 739.50 & 40 & & & & \\
\hline & $717 \mathrm{C}$ & $83 X-01-74-80$ & 749.74 & 40 & & & & \\
\hline & $717 \mathrm{C}$ & $84 \mathrm{X}-03-95-100$ & 762.45 & 20 & & & CN8? & \\
\hline & $717 \mathrm{C}$ & $85 X-02-98-104$ & 770.48 & 40 & & & & \\
\hline & $717 \mathrm{C}$ & $86 \mathrm{X}-\mathrm{CC}-9-14$ & 777.89 & 20 & & & & \\
\hline & $717 \mathrm{C}$ & $87 X-01-61-66$ & 787.61 & 20 & & & & \\
\hline & $717 \mathrm{C}$ & $88 X-01-68-73$ & 797.18 & 20 & & & CN7? & $9.2^{*}$ \\
\hline \multirow[t]{6}{*}{$718-190$} & $718 \mathrm{C}$ & & $190-290$ & 100 & 150 & 50 & CN9-CN9 & ??-8.4? \\
\hline & $717 \mathrm{C}$ & $25 \mathrm{X}-1-106-111$ & 238.36 & 20 & & & & \\
\hline & $717 \mathrm{C}$ & $25 X-2-8-13$ & 238.88 & 20 & & & & \\
\hline & $717 \mathrm{C}$ & $26 \mathrm{X}-2-21-26$ & 248.50 & 20 & & & & \\
\hline & $717 \mathrm{C}$ & $27 X-C C-19-23$ & 257.61 & 20 & & & & \\
\hline & $717 \mathrm{C}$ & $29 X-1-70-75$ & 276.00 & 20 & & & & \\
\hline \multirow[t]{7}{*}{$718-290$} & $718 \mathrm{C}$ & & $290-390$ & $90+$ & 260 & 92 & CN9-CN7? & $8.4^{*}-10.0$ \\
\hline & $718 \mathrm{C}$ & $32 X-01-132-134$ & 305.12 & 10 & & & CN9 & $8.5^{*}$ \\
\hline & $718 \mathrm{C}$ & $33 \mathrm{X}-\mathrm{CC}-10-15$ & 313.63 & 20 & & & & \\
\hline & $718 \mathrm{C}$ & $36 \mathrm{X}-\mathrm{CC}-22-27$ & 343.42 & 20 & & & & \\
\hline & $718 \mathrm{C}$ & $38 \mathrm{X}-01-72-77$ & 361.52 & 20 & & & & \\
\hline & $718 \mathrm{C}$ & $40 X-C C-5-10$ & 380.41 & 20 & & & & \\
\hline & $718 \mathrm{C}$ & 40X-CC-SCRAPS & 380.00 & $n$ & & & CN7? & $9.7^{*}$ \\
\hline \multirow[t]{10}{*}{$718-390$} & $718 \mathrm{C}$ & & $390-460$ & 200 & 300 & 105 & CN7b-CN7b & $9.7-10.3$ \\
\hline & $718 \mathrm{C}$ & 4 41X-1-93-97 & 390.23 & 20 & & & & \\
\hline & $718 \mathrm{C}$ & $41 X-C C-30-35$ & 399.02 & 20 & & & & \\
\hline & $718 \mathrm{C}$ & $42 X-C C-13-19$ & 400.65 & 20 & & & & \\
\hline & $718 \mathrm{C}$ & $43 X-1-58-62$ & 408.88 & 20 & & & & \\
\hline & $718 \mathrm{C}$ & $44 X-1-48-52$ & 418.28 & 20 & & & & \\
\hline & $718 \mathrm{C}$ & $46 \mathrm{X}-1-103-108$ & 437.87 & 20 & & & & \\
\hline & $718 \mathrm{C}$ & $47 X-C C-29-34$ & 448.27 & 20 & & & & \\
\hline & $718 \mathrm{C}$ & $48 X-1-15-20$ & 455.95 & 20 & & & & \\
\hline & $718 \mathrm{C}$ & 48X-CC-PALEO & 456.50 & 40 & & & & \\
\hline
\end{tabular}


Appendix A (continued).

\begin{tabular}{|c|c|c|c|c|c|c|c|c|}
\hline $718-460$ & $718 \mathrm{C}$ & & $460-560$ & 160 & 425 & 160 & CNTb-CN6? & $10.3-10.8$ \\
\hline & $718 \mathrm{C}$ & $49 \mathrm{X}-1-33-38$ & 465.63 & 20 & & & & \\
\hline & $718 \mathrm{C}$ & $52 X-1-11-16$ & 493.91 & 20 & & & & \\
\hline & $718 \mathrm{C}$ & $54 \mathrm{X}-\mathrm{CC}-22-26$ & 514.03 & 20 & & & & \\
\hline & $718 \mathrm{C}$ & $55 \mathrm{X}-1-122-126$ & 523.52 & 20 & & & & \\
\hline & $718 \mathrm{C}$ & $56 \times-1-69-73$ & 532.49 & 20 & & & & \\
\hline & $718 \mathrm{C}$ & $56 \mathrm{X}-4-16-21$ & 536.46 & 20 & & & & \\
\hline & $718 \mathrm{C}$ & $57 X-5-23-28$ & 547.53 & 20 & & & & \\
\hline & $718 \mathrm{C}$ & $58 X-1-40-45$ & 551.20 & 20 & & & & \\
\hline \multirow[t]{13}{*}{$718-560$} & $718 \mathrm{C}$ & & $560-660$ & 240 & 460 & 150 & CN6?-CN5b? & $10.8-13.0^{*}$ \\
\hline & $718 \mathrm{C}$ & $59 X-2-78-83$ & 562.58 & 20 & & & & \\
\hline & $718 \mathrm{C}$ & $59 X-4-46-51$ & 565.26 & 20 & & & & \\
\hline & $718 \mathrm{C}$ & $61 X-1-72-76$ & 580.02 & 20 & & & & \\
\hline & $718 \mathrm{C}$ & $61 X-1-110-114$ & 580.40 & 20 & & & & \\
\hline & $718 \mathrm{C}$ & $61 X-2-69-73$ & 581.49 & 20 & & & & \\
\hline & $718 \mathrm{C}$ & $62 X-2-78-83$ & 591.08 & 20 & & & & \\
\hline & $718 \mathrm{C}$ & $65 X-5-119-124$ & 624.49 & 20 & & & & \\
\hline & $718 \mathrm{C}$ & $66 x-1-130-135$ & 628.10 & 20 & & & & \\
\hline & $718 \mathrm{C}$ & $66 x-2-16-20$ & 628.46 & 20 & & & & \\
\hline & $718 \mathrm{C}$ & $68 \mathrm{X}-\mathrm{CC}-10-14$ & 648.05 & 20 & & & & \\
\hline & $718 \mathrm{C}$ & $69 X-1-7-10$ & 655.37 & 20 & & & & \\
\hline & $718 \mathrm{C}$ & $69 X-1-42-46$ & 655.72 & 20 & & & & \\
\hline \multirow[t]{8}{*}{$718-660$} & $718 \mathrm{C}$ & & $660-760$ & 220 & 395 & 120 & CN5b?-CN4? & $13.0^{*}-15.7^{*}$ \\
\hline & $718 \mathrm{C}$ & $70 \mathrm{X}-1-48-53$ & 665.16 & 20 & & & & \\
\hline & $718 \mathrm{C}$ & $70 X-1-36-41$ & 665.28 & 20 & & & & \\
\hline & $718 \mathrm{C}$ & $71 X-4-103-108$ & 679.83 & 20 & & & & \\
\hline & $718 \mathrm{C}$ & $71 X-5-43-47$ & 680.73 & 20 & & & & \\
\hline & $718 \mathrm{C}$ & $72 X-2-58-63$ & 685.88 & 20 & & & & \\
\hline & $718 \mathrm{C}$ & $72 X-2-125-130$ & 686.55 & 20 & & & & \\
\hline & $718 \mathrm{C}$ & |73X-1-136-141 & 694.66 & 20 & & & & \\
\hline \multirow{5}{*}{ SAMPLE\# } & SITE & SAMPLES & $\begin{array}{l}\text { DEPTH } \\
\text { (mbsl) }\end{array}$ & VOLUME (cc) & $\begin{array}{l}\text { INITIAL DRY } \\
\text { WEIGHT (g) }\end{array}$ & $\begin{array}{c}>63 \text { um } \\
\text { WEIGHT (g) }\end{array}$ & $\begin{array}{c}\text { NANNOFOSSIL } \\
\text { ZONE }\end{array}$ & $\begin{array}{l}\text { DEPOSITIONAL } \\
\text { AGE (Ma) }\end{array}$ \\
\hline & $718 \mathrm{C}$ & |73X-2-20-24 & 695.00 & 20 & & & & \\
\hline & $718 \mathrm{C}$ & $74 \mathrm{X}-\mathrm{CC}-30-35$ & 704.75 & 20 & & & & \\
\hline & $718 \mathrm{C}$ & $77 X-C C-30-35$ & 731.97 & 20 & & & & \\
\hline & $718 \mathrm{C}$ & $79 X-C C-20-25$ & 754.40 & 20 & & & & \\
\hline \multirow[t]{12}{*}{$718-760$} & $718 \mathrm{C}$ & & $760-860$ & 240 & 519 & 116 & $\mathrm{CN} 3 / 4$ & $15.7^{*}-16.8^{*}$ \\
\hline & $718 \mathrm{C}$ & $80 \mathrm{X}-01-43-47$ & 760.23 & 20 & & & $\mathrm{CN} 3 / 4$ & $16.1^{*}$ \\
\hline & $718 \mathrm{C}$ & $81 \mathrm{X}-\mathrm{CC}-18-22$ & 772.81 & 20 & & & $\mathrm{CN} 3$ & \\
\hline & $718 \mathrm{C}$ & $82 X-01-3-8$ & 778.83 & 20 & & & & \\
\hline & $718 \mathrm{C}$ & $83 \mathrm{X}-01-57-61$ & 788.87 & 20 & & & & \\
\hline & $718 \mathrm{C}$ & $85 X-01-43-47$ & 807.73 & 20 & & & & \\
\hline & $718 \mathrm{C}$ & $86 \times-01-44-49$ & 817.24 & 20 & & & & \\
\hline & $718 \mathrm{C}$ & $86 \mathrm{X}-02-14-19$ & 818.44 & 20 & & & & \\
\hline & $718 \mathrm{C}$ & 87X-CC-26-31 & 828.50 & 20 & & & & \\
\hline & $718 \mathrm{C}$ & $88 \mathrm{X}-01-37-42$ & 836.17 & 20 & & & & \\
\hline & $\begin{array}{l}718 C \\
718 C\end{array}$ & \begin{tabular}{|l}
$89 \mathrm{X}-01-21-26$ \\
$89 \mathrm{X}-\mathrm{CC}-23-28$
\end{tabular} & $\begin{array}{l}845.51 \\
846.03\end{array}$ & $\begin{array}{l}20 \\
20\end{array}$ & & & & \\
\hline & $\begin{array}{l}718 \mathrm{C} \\
718 \mathrm{C}\end{array}$ & $\begin{array}{l}89 X-C C-23-28 \\
90 \times-02-53-57\end{array}$ & $\begin{array}{l}846.03 \\
856.83\end{array}$ & $\begin{array}{l}20 \\
20\end{array}$ & & & $\mathrm{CN} 3 / 4$ & $16.8^{*}$ \\
\hline \multirow[t]{12}{*}{$718-860$} & $718 \mathrm{C}, \mathrm{E}$ & & $860-960$ & 340 & 620 & 162 & $\mathrm{CN} 3 / 4$ & $16.8^{*}-17.2^{*}$ \\
\hline & $718 \mathrm{C}$ & $91 X-1-39-45$ & 864.68 & 40 & & & $\mathrm{CN} 3 / 4$ & $16.8^{*}$ \\
\hline & $718 \mathrm{C}$ & $93 X-1-11-17$ & 878.11 & 40 & & & & \\
\hline & $718 \mathrm{C}$ & 93X-CC-20-24 & 878.79 & 20 & & & & \\
\hline & $718 \mathrm{C}$ & $95 X-1-6-11$ & 897.06 & 20 & & & & \\
\hline & $718 \mathrm{C}$ & $96 \times-C C-17-23$ & 906.97 & 40 & & & & \\
\hline & $718 \mathrm{C}$ & $97 X-1-9-11$ & 916.09 & 20 & & & & \\
\hline & $718 \mathrm{C}$ & $97 \mathrm{X}-1-36-40$ & 916.25 & 20 & & & & \\
\hline & $718 \mathrm{C}$ & $98 X-C C-5-9$ & 925.55 & 20 & & & & \\
\hline & $718 \mathrm{E}$ & 2R-3-69-75 & 942.75 & 40 & & & & \\
\hline & $718 \mathrm{E}$ & $2 R-3-94-100$ & 943.54 & 40 & & & & \\
\hline & $718 \mathrm{E}$ & 2R-3-130-136 & 943.90 & 40 & & & $\mathrm{CN} 3 / 4$ & $17.2^{\star}$ \\
\hline
\end{tabular}




\section{APPENDIX B}

Fission-track Age Determinations

Individual age determinations were calculated using the equation:

$$
t=\frac{1}{\lambda_{d}} \ln \left[1+\frac{\lambda_{d} \zeta \rho_{s} \rho_{d}}{2 \rho_{i}}\right]
$$

where: $\mathrm{t}=$ apatite fission-track age

$\lambda_{d}=$ total decay constant for ${ }^{238} \mathrm{U}$

$\zeta=$ the zeta calibration factor

$\rho_{s}=$ the density of spontaneous tracks

$\rho_{i}=$ the density of induced tracks

$\rho_{d}=$ the density of tracks in the fluence monitors

The total decay constant for ${ }^{238} \mathrm{U}\left(\lambda_{d}\right)$ used is $1.551 \times 10^{-10}$ $\mathrm{yr}^{-1}$. As discussed in the text, the zeta calibration factor $(\zeta)$ was determined to be $322 \pm 20 \mathrm{yr} /\left(\operatorname{tracks} \cdot \mathrm{cm}^{2}\right)$. In practice, because equivalent sized counting areas are used, the ratio $N_{s} / N_{i}$ was substituted for $\rho_{s} / \rho_{i}$, where $N_{s}=$ the number of spontaneous tracks counted and $N_{i}=$ the number of induced tracks counted in the mica. For the density of tracks in the fluence monitors $\left(\rho_{d}\right)$, the mean value of $2.961 \times 10^{6}$ tracks/ $\mathrm{cm}^{2}$ is used as no fluence gradients were detected in the reactor tubes.

This appendix contains data tables for the determination of fission-track ages of thirty individual apatite grains per dated samples. On each table the following information is given:

Sample - the first digit corresponds to the last digit of the Site number $(7=$ Site $717,8=$ Site 718$)$, digits following the hypen correspond to the depth (mbsf) to the top of the sampled interval.

NS $=$ number of spontaneous tracks counted $\left(N_{s}\right)$

$\mathrm{NI}=$ number of induced tracks counted $\left(N_{i}\right)$

Ratio $=$ the ratio of spontaneous and induced tracks counted $\left(N_{s} / N_{i}\right)$

Area Units = number of microscopic grid units in which tracks were counted, where one unit counting area is equal to $8.551 \times 10^{-7} \mathrm{~cm}^{2}$

Rho $\mathrm{S}=$ density of spontaneous tracks $\left(\right.$ tracks $\left./ \mathrm{cm}^{2}\right)$

Rho $\mathrm{I}=$ density of induced tracks (tracks $/ \mathrm{cm}^{2}$ )

Age $=$ single apatite grain fission-track age $(\mathrm{Ma})$

$95 \%$ C.I. $=$ the $95 \%$ confidence interval of the age determination (m.y.)

Methods used for calculating confidence intervals for single-grain ages, mean (pooled) sample ages, and weightedmean samples ages are given below:

(i) for single-grain age determinations of $95 \%$ C.I. $=1.96$ $\sigma$, where:

$$
\sigma=t\left[\frac{1}{N_{s}}+\frac{1}{N_{i}}+\frac{1}{N_{d}}+\frac{\sigma_{\zeta}^{2}}{\zeta^{2}}\right]^{1 / 2}
$$

and:

$t=$ fission-track age

$N_{s}=$ number of spontaneous tracks counted

$N_{i}=$ number of induced tracks counted

$N_{d}=$ number of induced tracks counted in the mica detectors covering the fluence monitors $\left(N_{d}=10183\right)$

$\zeta=$ mean of the zeta calibration factor determinations

$\sigma_{\zeta}=$ standard deviation about the mean zeta
For grains with 0 ages (no spontaneous tracks observed) uncertainties were calculated by taking the uncertainty had a single spontaneous track been observed.

(ii) for mean (pooled) sample ages the $95 \%$ C.I. $=1.96 \sigma$, where $\sigma$ is given by equation B.2 also, but here:

$N_{s}=\Sigma N_{s}$, total number of spontaneous tracks counted for all grains

$N_{i}=\Sigma N_{i}$, total number of induced tracks counted for all grains

where the mean (pooled) age is given by substituting $\Sigma N_{s} / \Sigma N_{i}$ for $\sigma_{s} / \sigma_{i}$ in equation B.1.

(iii) for weighted-mean sample ages the $95 \%$ C.I. $=$ $1.96 \sigma(n)^{-1 / 2}$, where the mean and standard deviation are given by:

$$
\begin{gathered}
\bar{t}=\frac{\sum \frac{t_{i}}{\sigma_{i}^{2}}}{\sum \frac{1}{\sigma_{i}^{2}}} \\
\sigma=\left[\frac{n \Sigma \frac{\left(t_{i}-\bar{t}\right)^{2}}{\sigma_{i}^{2}}}{(n-1) \Sigma \frac{1}{\sigma_{i}^{2}}}\right]^{1 / 2}
\end{gathered}
$$

where:

$t_{i}=$ fission-track age of $\mathrm{i}$-th grain

$\bar{t}=$ weighted mean of the individual grain ages

$\sigma_{i}=$ standard deviation about the fission track age of the i-th grain (equation B.2)

$n=$ the number of grains for which ages were determined.

Also reported is the chi-squared $\left(\chi^{2}\right)$ value (Galbraith, 1980; Green, 1981), which tests the hypothesis that the spread in single grain ages may be solely due to Poisson fluctuation of radioactive decay. The probability of exceeding the $x^{2}$ value for various levels of confidence is found from the reduced chi-squared value $\left(\chi_{v}^{2}\right)$ given by:

$$
\chi_{v}^{2}=\frac{\chi^{2}}{v}
$$

where $v=$ the number of degrees of freedom. Green (1981) suggests that a $5 \%$ probability of equaling or exceeding $\chi^{2}$ be taken as the cut-off for testing the hypothesis that the distribution of ages in a sample are derived from a single population (i.e., single-aged source terranes). For samples dated in this study, $v=29$, and at the $5 \%$ level the reduced chi-squared value $\left(\chi_{v}^{2}\right)$ is 1.47 (Bevington, 1969). Thus, all samples except $7-0$, and 8-460, pass the $\chi^{2}$ test at this level. Green (1981) has suggested taking the unweighted-mean age as being more representative for samples that fail the $\chi^{2}$ test. We feel that the weighted-mean age given by equation B.3 is more representative in this case as it accounts for the uncertainty associated with single-grain age determinations. For consistency we use the mean (pooled) age for all samples; however, we also report the weighted-mean age in Appendix B. The uncertainties associated with either sample age calculation method overlap for all cases; thus, the use of either age would not significantly alter the interpretations presented. 
SAMPLE: $7-0$

\begin{tabular}{|c|c|c|c|c|c|c|c|c|}
\hline Grain & NS & $\mathrm{NI}$ & $\begin{array}{l}\text { Area } \\
\text { Units } \\
\end{array}$ & Ratio & Rho S & Rho I & Age (Ma) & $\begin{array}{c}95 \% \text { C.I. } \\
(m . y .)\end{array}$ \\
\hline 1 & 6 & 398 & 90 & 0.0151 & $7.80 E+04$ & $5.17 E+06$ & 7.2 & 5.8 \\
\hline 2 & 2 & 274 & 100 & 0.0073 & $2.34 E+04$ & $3.20 E+06$ & 3.5 & 4.8 \\
\hline 3 & 1 & 88 & 36 & 0.0114 & $3.25 E+04$ & $2.86 E+06$ & 5.4 & 10.7 \\
\hline 4 & 5 & 169 & 81 & 0.0296 & $7.22 E+04$ & $2.44 E+06$ & 14.1 & 12.6 \\
\hline 5 & 3 & 209 & 90 & 0.0144 & $3.90 E+04$ & $2.72 E+06$ & 6.8 & 7.8 \\
\hline 6 & 5 & 484 & 90 & 0.0103 & $6.50 E+04$ & $6.29 E+06$ & 4.9 & 4.3 \\
\hline 7 & 4 & 298 & 90 & 0.0134 & $5.20 E+04$ & $3.87 E+06$ & 6.4 & 6.3 \\
\hline 8 & 0 & 199 & 80 & 0.0000 & $0.00 E+00$ & $2.91 E+06$ & 0.0 & 4.7 \\
\hline 9 & 0 & 120 & 100 & 0.0000 & $0.00 E+00$ & $1.40 E+06$ & 0.0 & 7.8 \\
\hline 10 & 6 & 111 & 70 & 0.0541 & $1.00 E+05$ & $1.85 E+06$ & 25.7 & 21.2 \\
\hline 11 & 4 & 318 & 72 & 0.0126 & $6.50 E+04$ & $5.17 E+06$ & 6.0 & 5.9 \\
\hline 12 & 0 & 86 & 90 & 0.0000 & $0.00 E+00$ & $1.12 E+06$ & 0.0 & 10.9 \\
\hline 13 & 3 & 260 & 80 & 0.0115 & $4.39 E+04$ & $3.80 E+06$ & 5.5 & 6.3 \\
\hline 14 & 3 & 188 & 90 & 0.0160 & $3.90 E+04$ & $2.44 E+06$ & 7.6 & 8.7 \\
\hline 15 & 1 & 555 & 80 & 0.0018 & $1.46 E+04$ & $8.11 E+06$ & 0.9 & 1.7 \\
\hline 16 & 2 & 540 & 90 & 0.0037 & $2.60 E+04$ & $7.02 E+06$ & 1.8 & 2.5 \\
\hline 17 & 3 & 560 & 100 & 0.0054 & $3.51 E+04$ & $6.55 E+06$ & 2.6 & 2.9 \\
\hline 18 & 1 & 117 & 25 & 0.0085 & $4.68 \mathrm{E}+04$ & $5.47 E+06$ & 4.1 & 8.0 \\
\hline 19 & 5 & 282 & 64 & 0.0177 & $9.14 E+04$ & $5.15 E+06$ & 8.4 & 7.5 \\
\hline 20 & 2 & 77 & 90 & 0.0260 & $2.60 E+04$ & $1.00 E+06$ & 12.4 & 17.4 \\
\hline 21 & 2 & 62 & 100 & 0.0323 & $2.34 E+04$ & $7.25 E+05$ & 15.4 & 21.6 \\
\hline 22 & 3 & 284 & 100 & 0.0106 & $3.51 E+04$ & $3.32 E+06$ & 5.0 & 5.7 \\
\hline 23 & 0 & 170 & 100 & 0.0000 & $0.00 E+00$ & $1.99 E+06$ & 0.0 & 5.5 \\
\hline 24 & 3 & 378 & 90 & 0.0079 & $3.90 \mathrm{E}+04$ & $4.91 E+06$ & 3.8 & 4.3 \\
\hline 25 & 0 & 249 & 100 & 0.0000 & $0.00 E+00$ & $2.91 E+06$ & 0.0 & 3.8 \\
\hline 26 & 2 & 186 & 42 & 0.0108 & $5.57 E+04$ & $5.18 E+06$ & 5.1 & 7.1 \\
\hline 27 & 2 & 328 & 100 & 0.0061 & $2.34 E+04$ & $3.84 E+06$ & 2.9 & 4.0 \\
\hline 28 & 1 & 158 & 100 & 0.0063 & $1.17 \mathrm{E}+04$ & $1.85 E+06$ & 3.0 & 5.9 \\
\hline 29 & 9 & 517 & 100 & 0.0174 & $1.05 E+05$ & $6.05 E+06$ & 8.3 & 5.5 \\
\hline \multirow[t]{2}{*}{30} & 1 & 252 & 100 & 0.0040 & $1.17 E+04$ & $2.95 E+06$ & 1.9 & 3.7 \\
\hline & 79 & 7917 & 2540 & 0.0100 & & & 4.8 & 1.1 \\
\hline Chi- & valu & & uced ch & red value & 1.94 & for 29 degre & freedom & \\
\hline
\end{tabular}

$\begin{array}{rlrl}\text { mean }(\text { pooled) age }= & 4.8 \mathrm{Ma} & 95 \% \mathrm{C} . \mathrm{I}= & 1.1 \mathrm{~m} . \mathrm{y} . \\ \text { weighted-mean age }= & 2.7 \mathrm{Ma} & 95 \% \mathrm{C} . \mathrm{I} .= & 1.0 \mathrm{~m} . \mathrm{y} .\end{array}$

SAMPLE: $7-220$

\begin{tabular}{|c|c|c|c|c|c|c|c|c|}
\hline Grain & NS & $\mathrm{NI}$ & $\begin{array}{l}\text { Area } \\
\text { Units }\end{array}$ & Ratio & Rho S & Rho I & Age (Ma) & $\begin{array}{c}95 \% \text { C.I. } \\
\text { (m.y.) }\end{array}$ \\
\hline 1 & 2 & 181 & 80 & 0.0110 & $2.92 E+04$ & $2.65 E+06$ & 5.3 & 7.3 \\
\hline 2 & 3 & 242 & 100 & 0.0124 & $3.51 E+04$ & $2.83 E+06$ & 5.9 & 6.7 \\
\hline 3 & 2 & 92 & 70 & 0.0217 & $3.34 E+04$ & $1.54 E+06$ & 10.4 & 14.5 \\
\hline 4 & 1 & 231 & 64 & 0.0043 & $1.83 E+04$ & $4.22 E+06$ & 2.1 & 4.1 \\
\hline 5 & 0 & 96 & 80 & 0.0000 & $0.00 E+00$ & $1.40 E+06$ & 0.0 & 9.8 \\
\hline 6 & 2 & 75 & 40 & 0.0267 & $5.85 E+04$ & $2.19 E+06$ & 12.7 & 17.9 \\
\hline 7 & 2 & 93 & 56 & 0.0215 & $4.18 E+04$ & $1.94 E+06$ & 10.2 & 14.4 \\
\hline 8 & 6 & 203 & 68 & 0.0296 & $1.03 E+05$ & $3.49 E+06$ & 14.1 & 11.5 \\
\hline 9 & 3 & 280 & 56 & 0.0107 & $6.26 \mathrm{E}+04$ & $5.85 E+06$ & 5.1 & 5.8 \\
\hline 10 & 3 & 291 & 56 & 0.0103 & $6.26 \mathrm{E}+04$ & $6.08 E+06$ & 4.9 & 5.6 \\
\hline 11 & 8 & 369 & 54 & 0.0217 & $1.73 E+05$ & $7.99 E+06$ & 10.3 & 7.3 \\
\hline 12 & 2 & 116 & 100 & 0.0172 & $2.34 E+04$ & $1.36 \mathrm{E}+06$ & 8.2 & 11.5 \\
\hline 13 & 1 & 106 & 70 & 0.0094 & $1.67 E+04$ & $1.77 E+06$ & 4.5 & 8.9 \\
\hline 14 & 2 & 166 & 72 & 0.0120 & $3.25 E+04$ & $2.70 E+06$ & 5.7 & 8.0 \\
\hline 15 & 2 & 126 & 100 & 0.0159 & 2. $34 E+04$ & $1.47 E+06$ & 7.6 & 10.6 \\
\hline 16 & 1 & 117 & 100 & 0.0085 & $1.17 E+04$ & $1.37 E+06$ & 4.1 & 8.0 \\
\hline 17 & 5 & 272 & 90 & 0.0184 & $6.50 E+04$ & $3.53 E+06$ & 8.8 & 7.8 \\
\hline 18 & 2 & 228 & 70 & 0.0088 & $3.34 E+04$ & $3.81 E+06$ & 4.2 & 5.8 \\
\hline 19 & 3 & 310 & 66 & 0.0097 & $5.32 E+04$ & $5.49 E+06$ & 4.6 & 5.3 \\
\hline 20 & 0 & 157 & 100 & 0.0000 & $0.00 E+00$ & $1.84 E+06$ & 0.0 & 6.0 \\
\hline 21 & 4 & 112 & 50 & 0.0357 & $9.36 \mathrm{E}+04$ & $2.62 E+06$ & 17.0 & 17.0 \\
\hline 22 & 1 & 158 & 70 & 0.0063 & $1.67 E+04$ & $2.64 E+06$ & 3.0 & 5.9 \\
\hline 23 & 2 & 148 & 80 & 0.0135 & $2.92 E+04$ & $2.16 \mathrm{E}+06$ & 6.4 & 9.0 \\
\hline 24 & 2 & 89 & 25 & 0.0225 & $9.36 \mathrm{E}+04$ & $4.16 \mathrm{E}+06$ & 10.7 & 15.0 \\
\hline 25 & 1 & 314 & 100 & 0.0032 & $1.17 E+04$ & $3.67 E+06$ & 1.5 & 3.0 \\
\hline 26 & 5 & 176 & 80 & 0.0284 & $7.31 E+04$ & $2.57 \mathrm{E}+06$ & 13.5 & 12.1 \\
\hline 27 & 2 & 91 & 70 & 0.0220 & $3.34 E+04$ & $1.52 E+06$ & 10.5 & 14.7 \\
\hline 28 & 4 & 231 & 60 & 0.0173 & $7.80 E+04$ & $4.50 E+06$ & 8.2 & 8.2 \\
\hline 29 & 4 & 147 & 60 & 0.0272 & $7.80 E+04$ & $2.87 E+06$ & 13.0 & 12.9 \\
\hline \multirow[t]{2}{*}{30} & 1 & 181 & 50 & 0.0055 & $2.34 E+04$ & $4.23 E+06$ & 2.6 & 5.2 \\
\hline & 76 & 5398 & 2137 & 0.0141 & & & 6.7 & 1.6 \\
\hline
\end{tabular}

Chi-squared value $=27.07 \quad$ Reduced chi-squared value $=0.93 \quad$ for 29 degrees of freedom

$$
\begin{array}{rlll}
\text { mean }(\text { pooled) age }= & 6.7 \mathrm{Ma} & 95 \% \mathrm{C} . \mathrm{I}= & 1.6 \mathrm{~m} . \mathrm{y} . \\
\text { weighted-mean age }= & 4.5 \mathrm{Ma} & 95 \% \mathrm{C} . \mathrm{l}= & 1.2 \mathrm{~m} . \mathrm{y}
\end{array}
$$


Appendix B (continued).

\begin{tabular}{|c|c|c|c|c|c|c|c|c|}
\hline Grain & NS & $\mathrm{NI}$ & $\begin{array}{l}\text { Area } \\
\text { Units } \\
\end{array}$ & $\begin{array}{l}\text { AMPLE: } \\
\text { Ratio }\end{array}$ & Rhos & Rhol & Age (Ma) & $\begin{array}{c}95 \% \text { c.l. } \\
\text { (m.y.) }\end{array}$ \\
\hline 1 & 5 & 355 & 100 & 0.0141 & $5.85 E+04$ & $4.15 E+06$ & 6.7 & 5.9 \\
\hline 2 & 17 & 554 & 100 & 0.0307 & $1.99 E+05$ & $6.48 \mathrm{E}+06$ & 14.6 & 7.1 \\
\hline 3 & 1 & 110 & 80 & 0.0091 & $1.46 E+04$ & $1.61 E+06$ & 4.3 & 8.5 \\
\hline 4 & 1 & 97 & 60 & 0.0103 & $1.95 E+04$ & $1.89 E+06$ & 4.9 & 9.7 \\
\hline 5 & 10 & 362 & 40 & 0.0276 & $2.92 E+05$ & $1.06 E+07$ & 13.2 & 8.3 \\
\hline 6 & 9 & 587 & 100 & 0.0153 & $1.05 E+05$ & $6.86 E+06$ & 7.3 & 4.8 \\
\hline 7 & 3 & 203 & 72 & 0.0148 & $4.87 E+04$ & $3.30 E+06$ & 7.0 & 8.0 \\
\hline 8 & 2 & 174 & 45 & 0.0115 & $5.20 E+04$ & $4.52 E+06$ & 5.5 & 7.6 \\
\hline 9 & 2 & 134 & 100 & 0.0149 & $2.34 E+04$ & $1.57 E+06$ & 7.1 & 9.9 \\
\hline 10 & 5 & 222 & 35 & 0.0225 & $1.67 E+05$ & $7.42 E+06$ & 10.7 & 9.5 \\
\hline 11 & 2 & 118 & 85 & 0.0169 & $2.75 E+04$ & $1.62 E+06$ & 8.1 & 11.3 \\
\hline 12 & 7 & 227 & 35 & 0.0308 & $2.34 E+05$ & $7.58 E+06$ & 14.7 & 11.1 \\
\hline 13 & 1 & 170 & 70 & 0.0059 & $1.67 E+04$ & $2.84 E+06$ & 2.8 & 5.5 \\
\hline 14 & 0 & 24 & 90 & 0.0000 & $0.00 E+00$ & $3.12 E+05$ & 0.0 & 39.7 \\
\hline 15 & 3 & 302 & 80 & 0.0099 & 4. $39 E+04$ & $4.41 E+06$ & 4.7 & 5.4 \\
\hline 16 & 8 & 694 & 100 & 0.0115 & $9.36 E+04$ & $8.12 E+06$ & 5.5 & 3.8 \\
\hline 17 & 4 & 135 & 100 & 0.0296 & $4.68 \mathrm{E}+04$ & $1.58 E+06$ & 14.1 & 14.1 \\
\hline 18 & 0 & 134 & 80 & 0.0000 & $0.00 E+00$ & $1.96 E+06$ & 0.0 & 7.0 \\
\hline 19 & 8 & 215 & 100 & 0.0372 & $9.36 E+04$ & $2.51 E+06$ & 17.7 & 12.5 \\
\hline 20 & 4 & 297 & 64 & 0.0135 & $7.31 E+04$ & $5.43 E+06$ & 6.4 & 6.3 \\
\hline 21 & 8 & 179 & 50 & 0.0447 & $1.87 E+05$ & $4.19 E+06$ & 21.3 & 15.1 \\
\hline 22 & 6 & 333 & 100 & 0.0180 & $7.02 E+04$ & $3.89 E+06$ & 8.6 & 7.0 \\
\hline 23 & 11 & 445 & 100 & 0.0247 & $1.29 E+05$ & $5.20 E+06$ & 11.8 & 7.1 \\
\hline 24 & 7 & 447 & 80 & 0.0157 & $1.02 E+05$ & $6.53 E+06$ & 7.5 & 5.6 \\
\hline 25 & 5 & 182 & 50 & 0.0275 & $1.17 E+05$ & $4.26 E+06$ & 13.1 & 11.7 \\
\hline 26 & 2 & 135 & 50 & 0.0148 & $4.68 \mathrm{E}+04$ & $3.16 E+06$ & 7.1 & 9.9 \\
\hline 27 & 2 & 152 & 50 & 0.0132 & $4.68 E+04$ & 3.56E+06 & 6.3 & 8.8 \\
\hline 28 & 2 & 140 & 56 & 0.0143 & $4.18 \mathrm{E}+04$ & $2.92 \mathrm{E}+06$ & 6.8 & 9.5 \\
\hline 29 & 3 & 113 & 60 & 0.0265 & $5.85 E+04$ & $2.20 \mathrm{E}+06$ & 12.6 & 14.5 \\
\hline 30 & 5 & 293 & 70 & 0.0171 & $8.35 E+04$ & $4.89 E+06$ & 8.1 & 7.2 \\
\hline & 143 & 7533 & 2202 & 0.0190 & & & 9.0 & 1.6 \\
\hline
\end{tabular}

$$
\begin{array}{rlll}
\text { mean }(\text { pooled }) \text { age }= & 9.0 \mathrm{Ma} & 95 \% \text { C.I. }= & 1.6 \mathrm{~m} . \mathrm{y} . \\
\text { weighted-mean age }= & 7.3 \mathrm{Ma} & 95 \% \mathrm{C} . \mathrm{I}= & 1.3 \mathrm{~m} . \mathrm{y} .
\end{array}
$$

SAMPLE: $\quad 7-620$

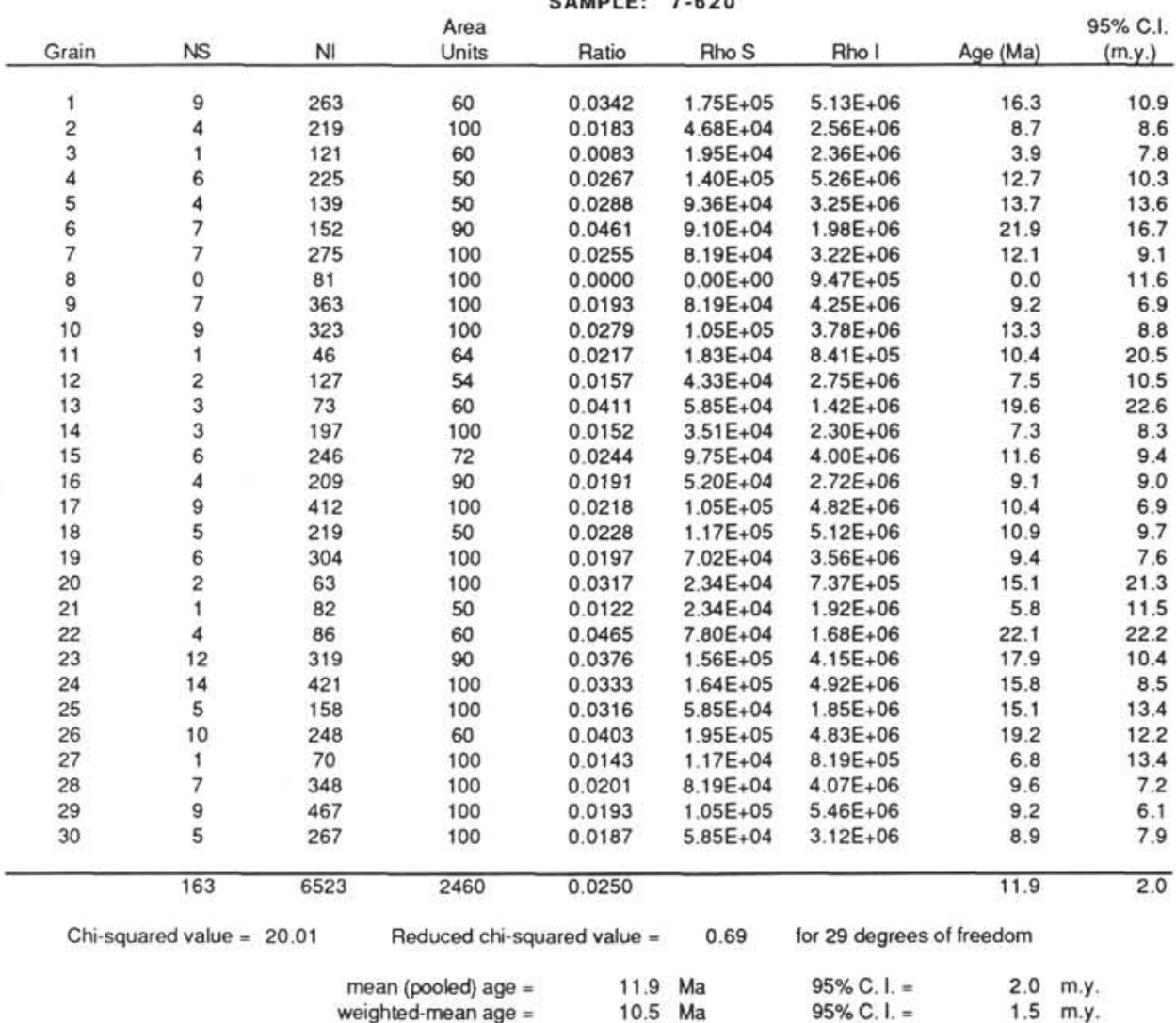


Appendix B (continued).

\begin{tabular}{|c|c|c|c|c|c|c|c|c|}
\hline Grain & NS & $\mathrm{NI}$ & $\begin{array}{l}\text { Area } \\
\text { Units }\end{array}$ & $\begin{array}{c}\text { SAMPLE: } \\
\text { Ratio } \\
\end{array}$ & Rho S & Rhol & Age (Ma) & $\begin{array}{c}95 \% \text { C.I. } \\
\text { (m.y.) }\end{array}$ \\
\hline 1 & 9 & 452 & 70 & 0.0199 & $1.50 E+05$ & $7.55 E+06$ & 9.5 & 6.3 \\
\hline 2 & 5 & 209 & 36 & 0.0239 & $1.62 E+05$ & $6.79 E+06$ & 11.4 & 10.1 \\
\hline 3 & 9 & 247 & 40 & 0.0364 & $2.63 E+05$ & $7.22 E+06$ & 17.3 & 11.6 \\
\hline 4 & 14 & 448 & 60 & 0.0313 & $2.73 E+05$ & $8.73 E+06$ & 14.9 & 8.0 \\
\hline 5 & 6 & 195 & 70 & 0.0308 & $1.00 E+05$ & $3.26 \mathrm{E}+06$ & 14.7 & 11.9 \\
\hline 6 & 8 & 421 & 100 & 0.0190 & $9.36 E+04$ & $4.92 E+06$ & 9.1 & 6.4 \\
\hline 7 & 6 & 273 & 70 & 0.0220 & $1.00 E+05$ & $4.56 E+06$ & 10.5 & 8.5 \\
\hline 8 & 9 & 308 & 50 & 0.0292 & $2.11 E+05$ & $7.20 E+06$ & 13.9 & 9.3 \\
\hline 9 & 14 & 351 & 64 & 0.0399 & $2.56 E+05$ & $6.41 E+06$ & 19.0 & 10.2 \\
\hline 10 & 2 & 91 & 40 & 0.0220 & $5.85 E+04$ & $2.66 E+06$ & 10.5 & 14.7 \\
\hline 11 & 14 & 447 & 100 & 0.0313 & $1.64 E+05$ & $5.23 E+06$ & 14.9 & 8.0 \\
\hline 12 & 7 & 202 & 70 & 0.0347 & $1.17 E+05$ & $3.37 E+06$ & 16.5 & 12.5 \\
\hline 13 & 5 & 115 & 100 & 0.0435 & $5.85 E+04$ & $1.34 E+06$ & 20.7 & 18.6 \\
\hline 14 & 7 & 122 & 35 & 0.0574 & $2.34 E+05$ & $4.08 E+06$ & 27.3 & 20.9 \\
\hline 15 & 7 & 164 & 100 & 0.0427 & $8.19 E+04$ & $1.92 E+06$ & 20.3 & 15.4 \\
\hline 16 & 3 & 38 & 50 & 0.0789 & $7.02 E+04$ & $8.89 E+05$ & 37.5 & 44.2 \\
\hline 17 & 6 & 254 & 64 & 0.0236 & $1.10 E+05$ & $4.64 E+06$ & 11.3 & 9.1 \\
\hline 18 & 2 & 64 & 35 & 0.0313 & $6.68 E+04$ & $2.14 E+06$ & 14.9 & 21.0 \\
\hline 19 & 11 & 436 & 100 & 0.0252 & $1.29 E+05$ & $5.10 E+06$ & 12.0 & 7.2 \\
\hline 20 & 5 & 185 & 80 & 0.0270 & $7.31 E+04$ & $2.70 E+06$ & 12.9 & 11.5 \\
\hline 21 & 3 & 53 & 100 & 0.0566 & $3.51 E+04$ & $6.20 E+05$ & 26.9 & 31.4 \\
\hline 22 & 4 & 119 & 100 & 0.0336 & $4.68 E+04$ & $1.39 E+06$ & 16.0 & 16.0 \\
\hline 23 & 3 & 119 & 100 & 0.0252 & $3.51 E+04$ & $1.39 E+06$ & 12.0 & 13.8 \\
\hline 24 & 1 & 37 & 80 & 0.0270 & $1.46 \mathrm{E}+04$ & $5.41 E+05$ & 12.9 & 25.6 \\
\hline 25 & 3 & 117 & 50 & 0.0256 & $7.02 E+04$ & $2.74 E+06$ & 12.2 & 14.0 \\
\hline 26 & 5 & 151 & 100 & 0.0331 & $5.85 E+04$ & $1.77 E+06$ & 15.8 & 14.1 \\
\hline 27 & 8 & 237 & 80 & 0.0338 & $1.17 \mathrm{E}+05$ & $3.46 \mathrm{E}+06$ & 16.1 & 11.4 \\
\hline 28 & 5 & 175 & 30 & 0.0286 & $1.95 E+05$ & $6.82 \mathrm{E}+06$ & 13.6 & 12.1 \\
\hline 29 & 8 & 235 & 100 & 0.0340 & $9.36 E+04$ & $2.75 E+06$ & 16.2 & 11.5 \\
\hline \multirow[t]{2}{*}{30} & 5 & 199 & 80 & 0.0251 & $7.31 E+04$ & $2.91 E+06$ & 12.0 & 10.6 \\
\hline & 194 & 6464 & 2154 & 0.0300 & & & 14.3 & 2.2 \\
\hline
\end{tabular}

$\begin{array}{rlll}\text { mean }(\text { pooled) age }= & 14.3 \mathrm{Ma} & 95 \% \mathrm{C} . \mathrm{I}= & 2.2 \mathrm{~m} . \mathrm{y} . \\ \text { weighted-mean age }= & 13.3 \mathrm{Ma} & 95 \% \mathrm{C} . \mathrm{I} .= & 1.3 \mathrm{~m} . \mathrm{y} .\end{array}$

SAMPLE: $8-290$

\begin{tabular}{|c|c|c|c|c|c|c|c|c|}
\hline Grain & NS & $\mathrm{NI}$ & $\begin{array}{l}\text { Area } \\
\text { Units }\end{array}$ & AMPLE & $8-290$ & Rho I & Age (Ma) & $\begin{array}{c}95 \% \text { C.I. } \\
\text { (m.y.) }\end{array}$ \\
\hline 1 & 11 & 273 & 45 & 0.0403 & $2.86 E+05$ & $7.09 E+06$ & 19.2 & 11.6 \\
\hline 2 & 2 & 163 & 100 & 0.0123 & $2.34 \mathrm{E}+04$ & $1.91 E+06$ & 5.8 & 8.2 \\
\hline 3 & 1 & 26 & 25 & 0.0385 & $4.68 E+04$ & $1.22 E+06$ & 18.3 & 36.6 \\
\hline 4 & 29 & 491 & 100 & 0.0591 & $3.39 E+05$ & $5.74 E+06$ & 28.1 & 10.7 \\
\hline 5 & 9 & 221 & 50 & 0.0407 & $2.11 E+05$ & $5.17 E+06$ & 19.4 & 13.0 \\
\hline 6 & 6 & 218 & 60 & 0.0275 & $1.17 E+05$ & $4.25 E+06$ & 13.1 & 10.7 \\
\hline 7 & 3 & 96 & 50 & 0.0313 & $7.02 E+04$ & $2.25 E+06$ & 14.9 & 17.1 \\
\hline 8 & 14 & 603 & 100 & 0.0232 & $1.64 E+05$ & $7.05 E+06$ & 11.1 & 5.9 \\
\hline 9 & 2 & 35 & 50 & 0.0571 & $4.68 E+04$ & $8.19 E+05$ & 27.2 & 38.8 \\
\hline 10 & 3 & 137 & 50 & 0.0219 & $7.02 E+04$ & $3.20 E+06$ & 10.4 & 11.9 \\
\hline 11 & 8 & 234 & 100 & 0.0342 & $9.36 E+04$ & $2.74 E+06$ & 16.3 & 11.5 \\
\hline 12 & 8 & 229 & 100 & 0.0349 & $9.36 E+04$ & $2.68 E+06$ & 16.6 & 11.8 \\
\hline 13 & 2 & 167 & 100 & 0.0120 & $2.34 E+04$ & $1.95 E+06$ & 5.7 & 8.0 \\
\hline 14 & 19 & 476 & 100 & 0.0399 & $2.22 E+05$ & $5.57 E+06$ & 19.0 & 8.8 \\
\hline 15 & 3 & 151 & 72 & 0.0199 & $4.87 E+04$ & $2.45 E+06$ & 9.5 & 10.8 \\
\hline 16 & 6 & 100 & 72 & 0.0600 & $9.75 E+04$ & $1.62 E+06$ & 28.5 & 23.6 \\
\hline 17 & 7 & 195 & 32 & 0.0359 & $2.56 \mathrm{E}+05$ & $7.13 E+06$ & 17.1 & 12.9 \\
\hline 18 & 7 & 403 & 90 & 0.0174 & $9.10 E+04$ & $5.24 E+06$ & 8.3 & 6.2 \\
\hline 19 & 6 & 103 & 36 & 0.0583 & $1.95 E+05$ & $3.35 E+06$ & 27.7 & 22.9 \\
\hline 20 & 9 & 473 & 90 & 0.0190 & $1.17 E+05$ & $6.15 E+06$ & 9.1 & 6.0 \\
\hline 21 & 9 & 268 & 100 & 0.0336 & $1.05 E+05$ & $3.13 E+06$ & 16.0 & 10.7 \\
\hline 22 & 11 & 374 & 100 & 0.0294 & $1.29 E+05$ & $4.37 E+06$ & 14.0 & 8.4 \\
\hline 23 & 2 & 117 & 100 & 0.0171 & $2.34 E+04$ & $1.37 E+06$ & 8.1 & 11.4 \\
\hline 24 & 13 & 427 & 100 & 0.0304 & $1.52 E+05$ & $4.99 E+06$ & 14.5 & 8.1 \\
\hline 25 & 2 & 44 & 100 & 0.0455 & $2.34 E+04$ & $5.15 E+05$ & 21.6 & 30.7 \\
\hline 26 & 12 & 307 & 90 & 0.0391 & $1.56 \mathrm{E}+05$ & $3.99 E+06$ & 18.6 & 10.8 \\
\hline 27 & 14 & 369 & 70 & 0.0379 & $2.34 E+05$ & $6.16 E+06$ & 18.1 & 9.7 \\
\hline 28 & 4 & 138 & 60 & 0.0290 & $7.80 E+04$ & $2.69 E+06$ & 13.8 & 13.7 \\
\hline 29 & 3 & 65 & 80 & 0.0462 & $4.39 E+04$ & $9.50 E+05$ & 22.0 & 25.5 \\
\hline \multirow[t]{2}{*}{30} & 22 & 346 & 60 & 0.0636 & $4.29 E+05$ & $6.74 \mathrm{E}+06$ & 30.2 & 13.2 \\
\hline & 247 & 7249 & 2282 & 0.0341 & & & 16.2 & 2.3 \\
\hline
\end{tabular}

Chi-squared value $=38.92 \quad$ Reduced chi-squared value $=1.34 \quad$ for 29 degrees of freedom

$\begin{array}{rlll}\text { mean }(\text { pooled) age }= & 16.2 \mathrm{Ma} & 95 \% \mathrm{C} . \mathrm{I}= & 2.3 \mathrm{~m} . \mathrm{y} . \\ \text { weighted-mean age }= & 13.5 \mathrm{Ma} & 95 \% \mathrm{C} . \mathrm{I}= & 2.2 \mathrm{~m} . \mathrm{y} .\end{array}$


Appendix B (continued).

SAMPLE: $8-460$

\begin{tabular}{|c|c|c|c|c|c|c|c|c|}
\hline Grain & NS & $\mathrm{NI}$ & $\begin{array}{l}\text { Area } \\
\text { Units }\end{array}$ & Ratio & Rho S & Rho I & Age (Ma) & $\begin{array}{c}95 \% \text { C.I. } \\
\text { (m.y.) }\end{array}$ \\
\hline 1 & 32 & 79 & 72 & 0.4051 & $5.20 E+05$ & $1.28 \mathrm{E}+06$ & 190.3 & 79.0 \\
\hline 2 & 1 & 59 & 100 & 0.0169 & $1.17 E+04$ & $6.90 E+05$ & 8.1 & 16.0 \\
\hline 3 & 4 & 102 & 50 & 0.0392 & $9.36 E+04$ & $2.39 E+06$ & 18.7 & 18.7 \\
\hline 4 & 4 & 78 & 72 & 0.0513 & $6.50 E+04$ & $1.27 E+06$ & 24.4 & 24.6 \\
\hline 5 & 6 & 148 & 100 & 0.0405 & $7.02 E+04$ & $1.73 E+06$ & 19.3 & 15.8 \\
\hline 6 & 5 & 133 & 40 & 0.0376 & $1.46 E+05$ & $3.89 E+06$ & 17.9 & 16.0 \\
\hline 7 & 16 & 418 & 80 & 0.0383 & $2.34 E+05$ & $6.11 E+06$ & 18.2 & 9.2 \\
\hline 8 & 17 & 422 & 90 & 0.0403 & $2.21 E+05$ & $5.48 E+06$ & 19.2 & 9.4 \\
\hline 9 & 7 & 126 & 10 & 0.0556 & $8.19 E+05$ & $1.47 E+07$ & 26.4 & 20.2 \\
\hline 10 & 8 & 419 & 100 & 0.0191 & $9.36 E+04$ & $4.90 E+06$ & 9.1 & 6.4 \\
\hline 11 & 5 & 141 & 10 & 0.0355 & $5.85 E+05$ & $1.65 E+07$ & 16.9 & 15.1 \\
\hline 12 & 2 & 53 & 90 & 0.0377 & $2.60 E+04$ & $6.89 E+05$ & 18.0 & 25.4 \\
\hline 13 & 19 & 232 & 100 & 0.0819 & $2.22 E+05$ & $2.71 E+06$ & 38.9 & 18.4 \\
\hline 14 & 9 & 176 & 100 & 0.0511 & $1.05 E+05$ & $2.06 E+06$ & 24.3 & 16.4 \\
\hline 15 & 8 & 325 & 100 & 0.0246 & $9.36 \mathrm{E}+04$ & $3.80 E+06$ & 11.7 & 8.3 \\
\hline 16 & 11 & 281 & 40 & 0.0391 & $3.22 E+05$ & $8.22 E+06$ & 18.6 & 11.3 \\
\hline 17 & 13 & 249 & 30 & 0.0522 & $5.07 E+05$ & $9.71 E+06$ & 24.8 & 13.9 \\
\hline 18 & 18 & 461 & 90 & 0.0390 & $2.34 E+05$ & $5.99 \mathrm{E}+06$ & 18.6 & 8.8 \\
\hline 19 & 8 & 185 & 100 & 0.0432 & $9.36 E+04$ & 2.16E+06 & 20.6 & 14.6 \\
\hline 20 & 3 & 46 & 90 & 0.0652 & $3.90 E+04$ & $5.98 \mathrm{E}+05$ & 31.0 & 36.3 \\
\hline 21 & 6 & 140 & 50 & 0.0429 & $1.40 E+05$ & $3.27 E+06$ & 20.4 & 16.7 \\
\hline 22 & 4 & 209 & 60 & 0.0191 & $7.80 E+04$ & $4.07 E+06$ & 9.1 & 9.0 \\
\hline 23 & 11 & 236 & 60 & 0.0466 & $2.14 E+05$ & $4.60 E+06$ & 22.2 & 13.5 \\
\hline 24 & 5 & 187 & 50 & 0.0267 & $1.17 E+05$ & $4.37 E+06$ & 12.7 & 11.3 \\
\hline 25 & 11 & 351 & 90 & 0.0313 & $1.43 E+05$ & $4.56 \mathrm{E}+06$ & 14.9 & 9.0 \\
\hline 26 & 13 & 276 & 60 & 0.0471 & $2.53 E+05$ & $5.38 E+06$ & 22.4 & 12.5 \\
\hline 27 & 5 & 259 & 100 & 0.0193 & $5.85 E+04$ & $3.03 E+06$ & 9.2 & 8.2 \\
\hline 28 & 20 & 213 & 50 & 0.0939 & $4.68 E+05$ & $4.98 E+06$ & 44.6 & 20.6 \\
\hline 29 & 1 & 80 & 70 & 0.0125 & $1.67 E+04$ & $1.34 E+06$ & 6.0 & 11.8 \\
\hline \multirow[t]{2}{*}{30} & 4 & 150 & 70 & 0.0267 & $6.68 E+04$ & $2.51 E+06$ & 12.7 & 12.6 \\
\hline & 276 & 6234 & 2124 & 0.0443 & & & 21.1 & 2.9 \\
\hline Chi- & valu & 7.39 & uced ct & red value & 7.15 & for 29 degre & freedom & \\
\hline
\end{tabular}

$$
\begin{array}{rlll}
\text { mean }(\text { pooled }) \text { age }= & 21.1 \mathrm{Ma} & 95 \% \mathrm{C} . \mathrm{I} .= & 2.9 \mathrm{~m} . \mathrm{y} . \\
\text { weighted-mean age }= & 15.9 \mathrm{Ma} & 95 \% \mathrm{C} . \mathrm{I} .= & 3.1 \mathrm{~m} . \mathrm{y} .
\end{array}
$$

SAMPLE: $8-660$

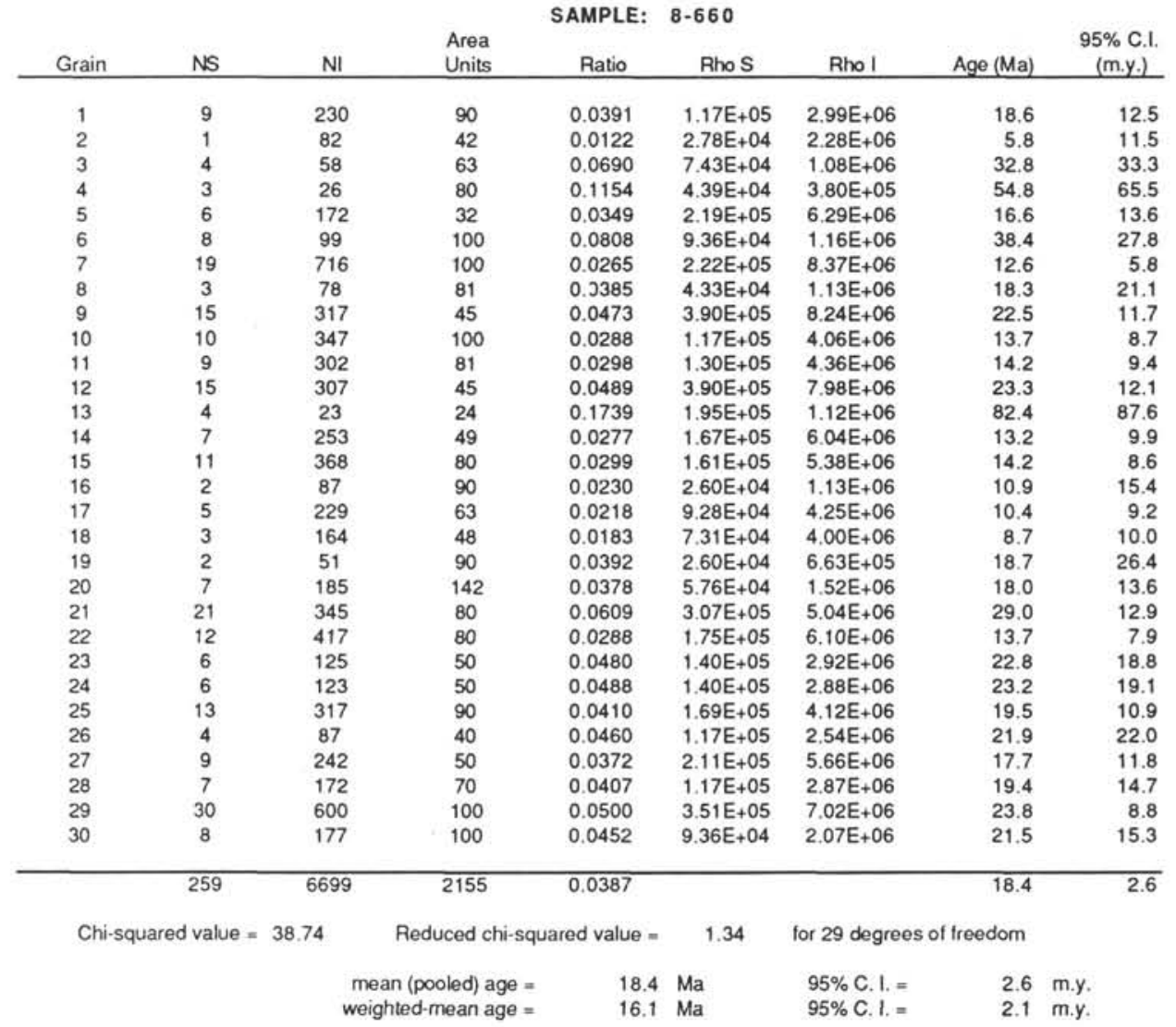


Appendix B (continued).

\begin{tabular}{|c|c|c|c|c|c|c|c|c|}
\hline Grain & NS & $\mathrm{NI}$ & $\begin{array}{c}\text { Area } \\
\text { Units } \\
\end{array}$ & AMPLE & Rho S & Rho I & Age (Ma) & $\begin{array}{c}95 \% \text { C.I. } \\
\text { (m.y.) }\end{array}$ \\
\hline 1 & 3 & 81 & 25 & 0.0370 & $1.40 \mathrm{E}+05$ & $3.79 E+06$ & 17.6 & 20.3 \\
\hline 2 & 9 & 256 & 80 & 0.0352 & $1.32 \mathrm{E}+05$ & $3.74 E+06$ & 16.7 & 11.2 \\
\hline 3 & 10 & 468 & 100 & 0.0214 & $1.17 E+05$ & $5.47 E+06$ & 10.2 & 6.4 \\
\hline 4 & 4 & 120 & 45 & 0.0333 & $1.04 E+05$ & $3.12 E+06$ & 15.9 & 15.8 \\
\hline 5 & 8 & 218 & 50 & 0.0367 & $1.87 E+05$ & $5.10 E+06$ & 17.5 & 12.4 \\
\hline 6 & 3 & 67 & 40 & 0.0448 & $8.77 E+04$ & $1.96 E+06$ & 21.3 & 24.7 \\
\hline 7 & 8 & 171 & 50 & 0.0468 & $1.87 E+05$ & $4.00 E+06$ & 22.3 & 15.8 \\
\hline 8 & 13 & 272 & 70 & 0.0478 & $2.17 E+05$ & $4.54 E+06$ & 22.7 & 12.7 \\
\hline 9 & 10 & 287 & 60 & 0.0348 & $1.95 E+05$ & $5.59 E+06$ & 16.6 & 10.5 \\
\hline 10 & 4 & 156 & 100 & 0.0256 & $4.68 E+04$ & $1.82 E+06$ & 12.2 & 12.1 \\
\hline 11 & 2 & 29 & 50 & 0.0690 & $4.68 E+04$ & $6.78 E+05$ & 32.8 & 47.0 \\
\hline 12 & 3 & 125 & 35 & 0.0240 & $1.00 E+05$ & $4.18 E+06$ & 11.4 & 13.1 \\
\hline 13 & 8 & 146 & 30 & 0.0548 & $3.12 E+05$ & $5.69 E+06$ & 26.1 & 18.6 \\
\hline 14 & 4 & 143 & 48 & 0.0280 & $9.75 E+04$ & $3.48 E+06$ & 13.3 & 13.3 \\
\hline 15 & 9 & 136 & 30 & 0.0662 & $3.51 \mathrm{E}+05$ & $5.30 E+06$ & 31.5 & 21.3 \\
\hline 16 & 3 & 71 & 49 & 0.0423 & $7.16 \mathrm{E}+04$ & $1.69 E+06$ & 20.1 & 23.3 \\
\hline 17 & 14 & 280 & 72 & 0.0500 & $2.27 E+05$ & $4.55 E+06$ & 23.8 & 12.9 \\
\hline 18 & 4 & 102 & 32 & 0.0392 & $1.46 \mathrm{E}+05$ & $3.73 E+06$ & 18.7 & 18.7 \\
\hline 19 & 3 & 57 & 56 & 0.0526 & $6.26 E+04$ & $1.19 E+06$ & 25.0 & 29.1 \\
\hline 20 & 15 & 375 & 80 & 0.0400 & 2.19E+05 & $5,48 E+06$ & 19.0 & 9.9 \\
\hline 21 & 2 & 62 & 64 & 0.0323 & $3.65 E+04$ & $1.13 E+06$ & 15.4 & 21.6 \\
\hline 22 & 11 & 319 & 100 & 0.0345 & $1.29 E+05$ & $3.73 E+06$ & 16.4 & 9.9 \\
\hline 23 & 3 & 92 & 35 & 0.0326 & $1.00 E+05$ & $3.07 E+06$ & 15.5 & 17.9 \\
\hline 24 & 5 & 131 & 24 & 0.0382 & $2.44 E+05$ & $6.38 E+06$ & 18.2 & 16.3 \\
\hline 25 & 8 & 142 & 35 & 0.0563 & $2.67 E+05$ & $4.74 E+06$ & 26.8 & 19.2 \\
\hline 26 & 3 & 46 & 50 & 0.0652 & $7.02 E+04$ & $1.08 E+06$ & 31.0 & 36.3 \\
\hline 27 & 3 & 101 & 40 & 0.0297 & $8.77 E+04$ & $2.95 E+06$ & 14,1 & 16.3 \\
\hline 28 & 7 & 142 & 30 & 0.0493 & $2.73 E+05$ & $5.54 E+06$ & 23.5 & 17.9 \\
\hline 29 & 2 & 49 & 60 & 0.0408 & $3.90 E+04$ & $9.55 E+05$ & 19.4 & 27.5 \\
\hline 30 & 3 & 81 & 24 & 0.0370 & $1.46 E+05$ & $3.95 E+06$ & 17.6 & 20.3 \\
\hline & 184 & 4725 & 1564 & 0.0389 & & & 18.5 & 3.0 \\
\hline
\end{tabular}

$\begin{array}{rlll}\text { mean (pooled) age }= & 18.5 \mathrm{Ma} & 95 \% \mathrm{C} . \mathrm{I} .= & 3.0 \mathrm{~m} . \mathrm{y} . \\ \text { weighted-mean age }= & 17.0 \mathrm{Ma} & 95 \% \mathrm{C} . \mathrm{I}= & 1.8 \mathrm{~m} . \mathrm{y} .\end{array}$

\begin{tabular}{|c|c|c|c|c|c|c|c|c|}
\hline Grain & NS & $\mathrm{NI}$ & $\begin{array}{l}\text { Area } \\
\text { Units } \\
\end{array}$ & $\begin{array}{l}\text { AMPLE: } \\
\text { Ratio }\end{array}$ & Rho S & Rho I & Age (Ma) & $\begin{array}{c}95 \% \text { C.I. } \\
\text { (m.y.) }\end{array}$ \\
\hline 1 & 11 & 205 & 56 & 0.0537 & $2.30 E+05$ & $4.28 E+06$ & 25.5 & 15.6 \\
\hline 2 & 4 & 191 & 50 & 0.0209 & $9.36 E+04$ & $4.47 E+06$ & 10.0 & 9.9 \\
\hline 3 & 8 & 225 & 63 & 0.0356 & $1.49 E+05$ & $4.18 E+06$ & 16.9 & 12.0 \\
\hline 4 & 16 & 438 & 81 & 0.0365 & $2.31 E+05$ & $6.32 E+06$ & 17.4 & 8.7 \\
\hline 5 & 5 & 311 & 50 & 0.0161 & $1.17 E+05$ & $7.27 E+06$ & 7.7 & 6.8 \\
\hline 6 & 6 & 112 & 60 & 0.0536 & $1.17 E+05$ & $2.18 E+06$ & 25.5 & 21.0 \\
\hline 7 & 13 & 311 & 63 & 0.0418 & $2.41 E+05$ & $5.77 E+06$ & 19.9 & 11.1 \\
\hline 8 & 4 & 162 & 100 & 0.0247 & $4.68 E+04$ & $1.89 E+06$ & 11.8 & 11.7 \\
\hline 9 & 8 & 259 & 90 & 0.0309 & $1.04 E+05$ & $3.37 E+06$ & 14.7 & 10.4 \\
\hline 10 & 6 & 318 & 80 & 0.0189 & $8.77 E+04$ & $4.65 \bar{E}+06$ & 9.0 & 7.3 \\
\hline 11 & 7 & 248 & 81 & 0.0282 & $1.01 E+05$ & $3.58 E+06$ & 13.4 & 10.1 \\
\hline 12 & 3 & 87 & 50 & 0.0345 & $7.02 E+04$ & $2.03 E+06$ & 16.4 & 18.9 \\
\hline 13 & 3 & 59 & 50 & 0.0508 & $7.02 E+04$ & $1.38 \mathrm{E}+06$ & 24.2 & 28.1 \\
\hline 14 & 1 & 31 & 56 & 0.0323 & $2.09 E+04$ & $6.47 E+05$ & 15.4 & 30.6 \\
\hline 15 & 9 & 241 & 50 & 0.0373 & $2.11 E+05$ & $5.64 \mathrm{E}+06$ & 17.8 & 11.9 \\
\hline 16 & 5 & 98 & 81 & 0.0510 & $7.22 E+04$ & $1.41 E+06$ & 24.3 & 21.9 \\
\hline 17 & 3 & 57 & 40 & 0.0526 & $8.77 E+04$ & $1.67 E+06$ & 25.0 & 29.1 \\
\hline 18 & 9 & 296 & 48 & 0.0304 & $2.19 E+05$ & $7.21 E+06$ & 14.5 & 9.6 \\
\hline 19 & 15 & 409 & 100 & 0.0367 & $1.75 E+05$ & $4.78 E+06$ & 17.5 & 9.1 \\
\hline 20 & 4 & 97 & 50 & 0.0412 & $9.36 E+04$ & $2.27 E+06$ & 19.6 & 19.7 \\
\hline 21 & 5 & 203 & 54 & 0.0246 & $1.08 E+05$ & $4.40 E+06$ & 11.7 & 10.4 \\
\hline 22 & 8 & 197 & 60 & 0.0406 & $1.56 E+05$ & $3.84 E+06$ & 19.3 & 13.7 \\
\hline 23 & 8 & 225 & 64 & 0.0356 & $1.46 \mathrm{E}+05$ & $4.11 \mathrm{E}+06$ & 16.9 & 12.0 \\
\hline 24 & 6 & 296 & 100 & 0.0203 & $7.02 E+04$ & $3.46 \mathrm{E}+06$ & 9.7 & 7.8 \\
\hline 25 & 12 & 415 & 80 & 0.0289 & $1.75 E+05$ & $6.07 E+06$ & 13.8 & 7.9 \\
\hline 26 & 5 & 105 & 54 & 0.0476 & $1.08 E+05$ & $2.27 E+06$ & 22.7 & 20.4 \\
\hline 27 & 4 & 143 & 50 & 0.0280 & $9.36 E+04$ & $3.34 E+06$ & 13.3 & 13.3 \\
\hline 28 & 6 & 111 & 80 & 0.0541 & $8.77 E+04$ & $1.62 E+06$ & 25.7 & 21.2 \\
\hline 29 & 6 & 227 & 60 & 0.0264 & $1.17 E+05$ & $4.42 E+06$ & 12.6 & 10.2 \\
\hline \multirow[t]{2}{*}{30} & 16 & 420 & 70 & 0.0381 & $2.67 E+05$ & $7.02 E+06$ & 18.1 & 9.1 \\
\hline & 216 & 6497 & 1971 & 0.0332 & & & 15.8 & 2.4 \\
\hline
\end{tabular}

$\begin{array}{rlll}\text { mean (pooled) age }= & 15.8 \mathrm{Ma} & 95 \% \mathrm{C} . \mathrm{I}= & 2.4 \mathrm{~m} . \mathrm{y} . \\ \text { weighted-mean age }= & 14.3 \mathrm{Ma} & 95 \% \mathrm{C} . \mathrm{I} .= & 1.7 \mathrm{~m} . \mathrm{y} .\end{array}$



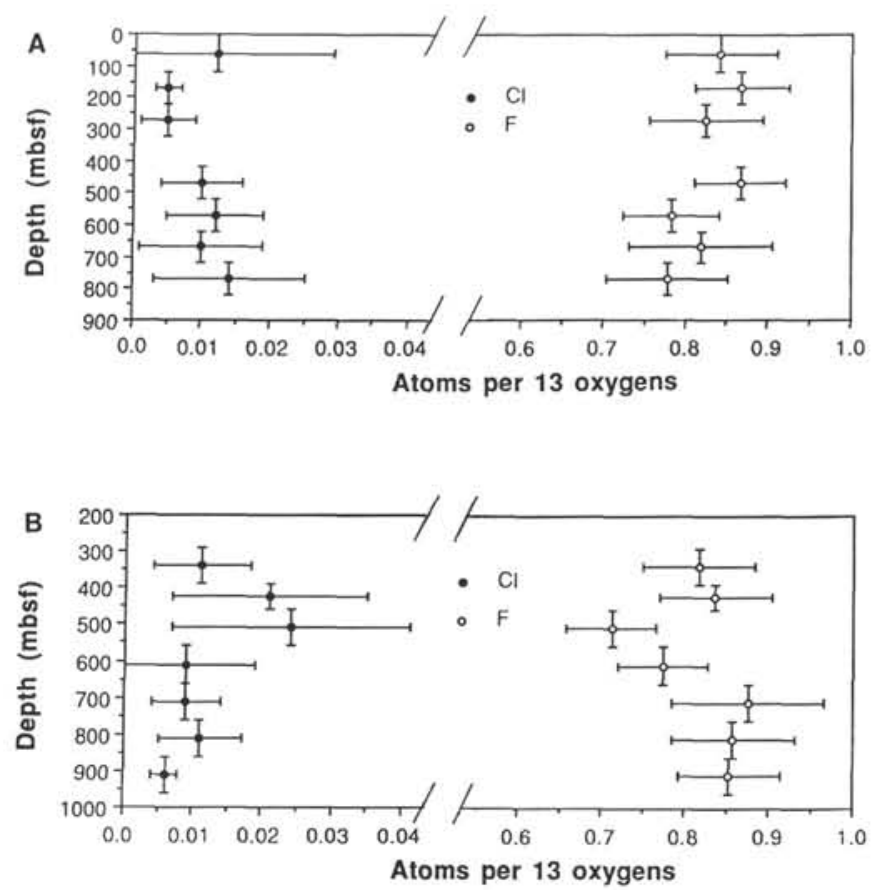

Figure 8. Mean number of $\mathrm{Cl}$ and $\mathrm{F}$ atoms per apatite molecule, as well as the standard error of the mean ( $95 \%$ confidence interval), for each sample are plotted against depth for A. Site 717 holes and B. Site 718 holes.

\section{APPENDIX C \\ Apatite Compositions}

Electron microprobe compositional data were determined for 20 randomly chosen apatites per sample to test the hypothesis that track-shortening trends reflect variations in sample-averaged apatite $\mathrm{Cl}$ content. $\mathrm{CaO},{ }^{205} \mathrm{P}, \mathrm{F}$, and $\mathrm{Cl}$ were analyzed by using the wavelength dispersive system set at a maximum count time of $60 \mathrm{~s}$ on a JEOL 733 electron microprobe. Operating conditions were $15 \mathrm{KeV}$ and a $20-\mathrm{nA}$ sample current. A $20-\mu \mathrm{m}$ beam diameter was used to minimize $\mathrm{F}$ burnoff. Avoidance of the $3-\mathrm{P}-\mathrm{K}_{\alpha}$ interference with $1-\mathrm{F}-\mathrm{K}_{\alpha}$ when analyzing for $\mathrm{F}$ was achieved by filtering out the higher order phosphorous peak using the single-channel analyzer. All analyses were converted to weight percent using the Bence-Albee reduction scheme. Determined weight percents for each element were converted to number of atoms per 13 oxygens for a $\mathrm{Ca}_{5}\left(\mathrm{PO}_{4}\right)_{3}(\mathrm{OH}, \mathrm{F}, \mathrm{Cl})$ molecule. The mean number of $\mathrm{Cl}$ and $\mathrm{F}$ atoms per apatite molecule as well as the standard error of the mean at the $95 \%$ confidence interval, for each sample, are plotted versus depth for Site 717 (Fig. 8A) and Site 718 (Fig. 8B) samples. All samples comprise predominantly of F-OH apatites containing on average less than 0.04 atoms of $\mathrm{Cl}$ per apatite molecule. No correlation between average anion composition and mean track length is observed. Thus, we conclude that the decrease in mean track length below 560 mbsf at Site 718 is not due to a decrease in apatite $\mathrm{Cl}$ content below this depth. 